\title{
Review
}

\section{An overview on the reactors to study drinking water biofilms}

\author{
I.B. Gomes ${ }^{a}$, M. Simões ${ }^{a}$, L.C. Simões ${ }^{a, b, *}$ \\ ${ }^{a}$ LEPABE, Department of Chemical Engineering, Faculty of Engineering, University of Porto, Rua Dr. Roberto Frias, \\ $s / n, 4200-465$ Porto, Portugal \\ ${ }^{\mathrm{b}}$ CEB - Centre of Biological Engineering, University of Minho, Campus de Gualtar, 4710-057 Braga, Portugal
}

\section{A R T I C L E I N F O}

Article history:

Received 31 January 2014

Received in revised form

21 May 2014

Accepted 22 May 2014

Available online 3 June 2014

Keywords:

Biofilm control

Biofilm monitoring

Drinking water

Reactor

\begin{abstract}
A B S T R A C T
The development of biofilms in drinking water distribution systems (DWDS) can cause pipe degradation, changes in the water organoleptic properties but the main problem is related to the public health. Biofilms are the main responsible for the microbial presence in drinking water (DW) and can be reservoirs for pathogens. Therefore, the understanding of the mechanisms underlying biofilm formation and behavior is of utmost importance in order to create effective control strategies. As the study of biofilms in real DWDS is difficult, several devices have been developed. These devices allow biofilm formation under controlled conditions of physical (flow velocity, shear stress, temperature, type of pipe material, etc), chemical (type and amount of nutrients, type of disinfectant and residuals, organic and inorganic particles, ions, etc) and biological (composition of microbial community - type of microorganism and characteristics) parameters, ensuring that the operational conditions are similar as possible to the DWDS conditions in order to achieve results that can be applied to the real scenarios. The devices used in DW biofilm studies can be divided essentially in two groups, those usually applied in situ and the bench top laboratorial reactors. The selection of a device should be obviously in accordance with the aim of the study and its advantages and limitations should be evaluated to obtain reproducible results that can be transposed into the reality of the DWDS. The aim of this review is to provide an overview on the main reactors used in DW biofilm studies, describing their characteristics and applications, taking into account their main advantages and limitations.
\end{abstract}

(c) 2014 Elsevier Ltd. All rights reserved.

\section{Contents}

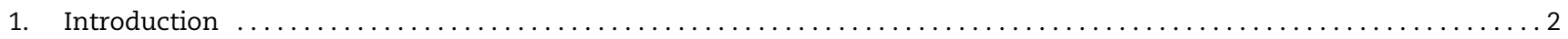

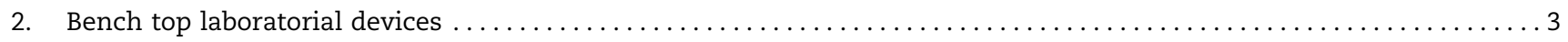

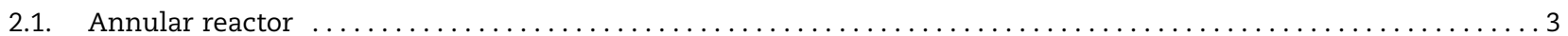

* Corresponding author. Centro de Engenharia Biológica, Universidade do Minho, Braga, Portugal. Tel.: +351 253604400; fax: +351 253604429.

E-mail address: luciachaves@deb.uminho.pt (L.C. Simões).

http://dx.doi.org/10.1016/j.watres.2014.05.039

0043-1354/@ 2014 Elsevier Ltd. All rights reserved. 


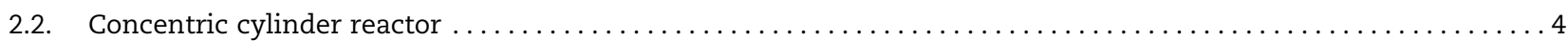

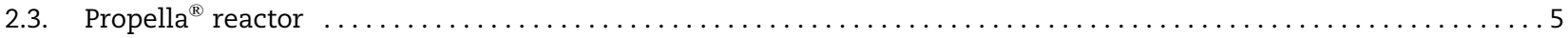

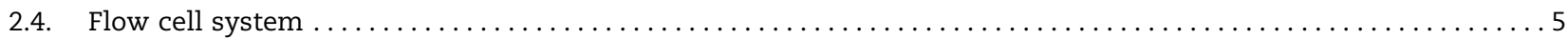

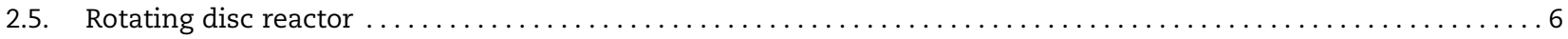

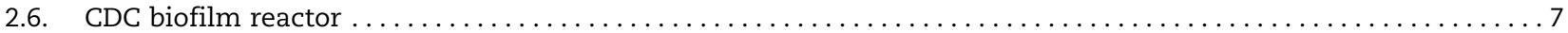

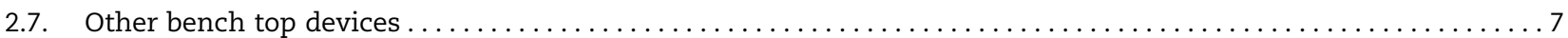

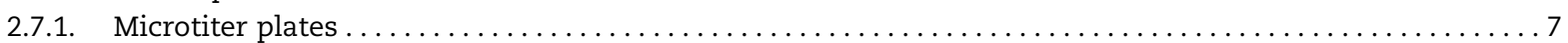

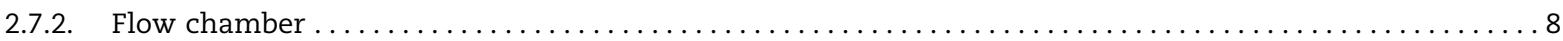

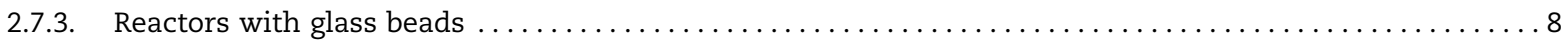

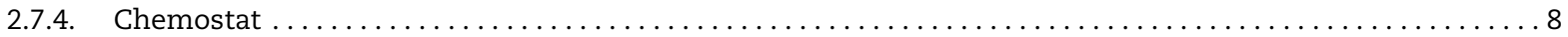

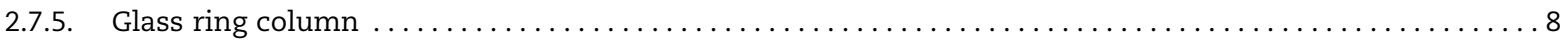

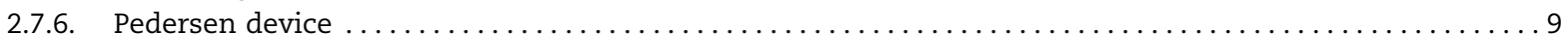

2.7.7. Loop with biofilm test-plug module $\ldots \ldots \ldots \ldots \ldots \ldots \ldots \ldots \ldots \ldots \ldots \ldots \ldots \ldots \ldots \ldots \ldots \ldots \ldots$

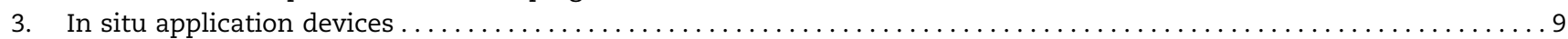

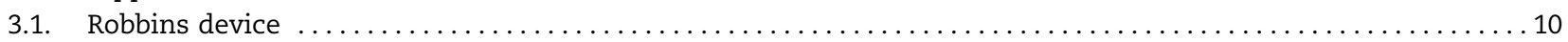

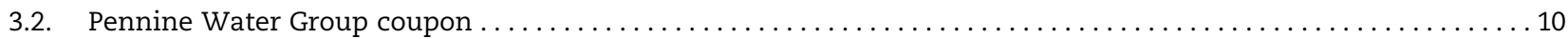

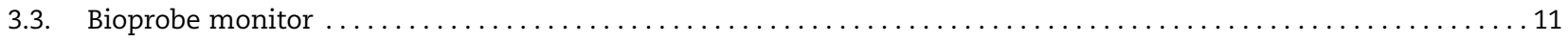

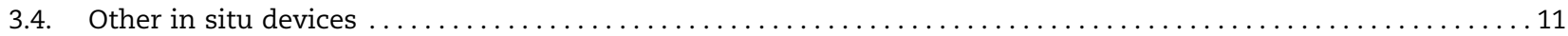

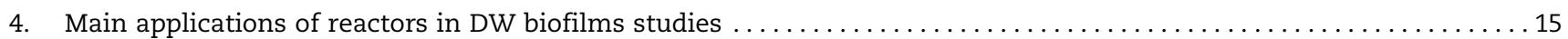

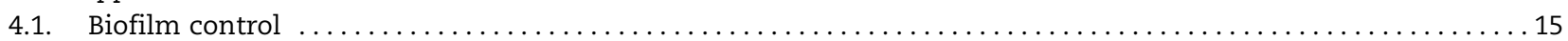

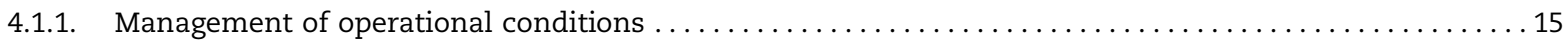

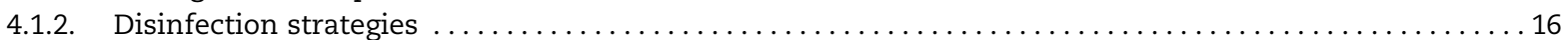

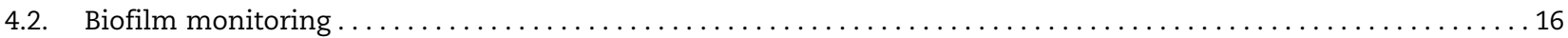

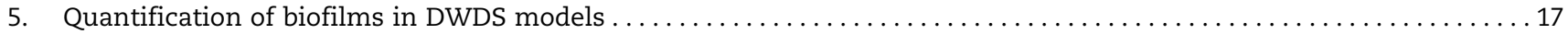

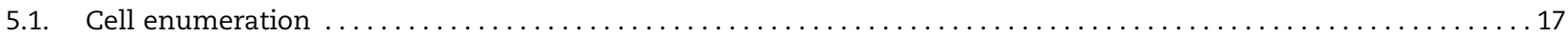

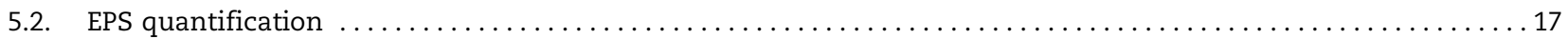

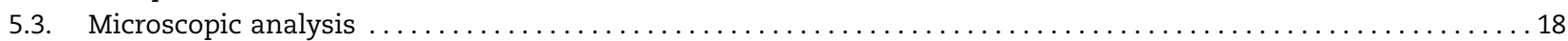

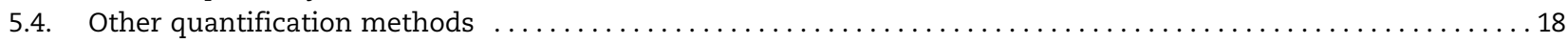

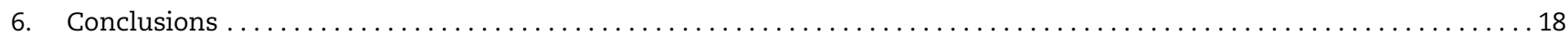

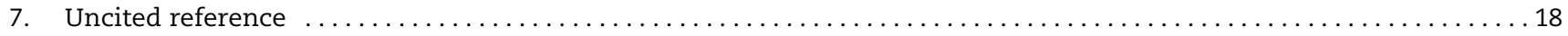

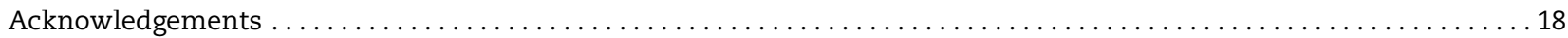

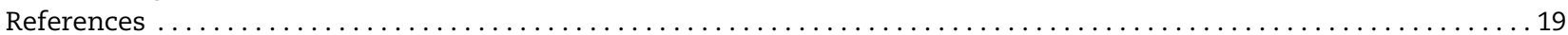

\section{Introduction}

There is a global concern that all the world population should have access to safe drinking water (DW). Even in the 21st century, there are many people without access to appropriate water, in quantity and/or quality, for the basic needs (WHO, 2011). The existence of DW distribution systems (DWDS) allows the management and supply of water for more people. However, there are several problems that can occur in a DWDS. From a microbiological perspective, the main problems reported in DWDS are the biocorrosion, biofilm formation, nitrification and also the occurrence and persistence of pathogenic organisms (Beech and Sunner, 2004; Camper, 2004; Emtiazi et al., 2004; Simões and Simões, 2013; Teng et al., 2008). Biofilms are considered to be the main source of microorganisms in DWDS that are fed with treated water (Berry et al., 2006; Yu et al., 2010). Biofilms are a set of microorganisms attached to a surface through exopolymers they produce, also known as extracellular polymeric substances (EPS). These are mainly proteins and polysaccharides that are involved in microbial protection from stress conditions (Fang et al., 2010). The main microorganisms that are commonly detected in DWDS are heterotrophic bacteria, particularly $\alpha-, \beta$ - and $\gamma$ - proteobacteria (Berry et al., 2006; Henne et al., 2012; Lu et al., 2013). Other bacterial groups included mycobacteria, firmicutes, acidobacteria, bacteroidetes, cyanobacteria, deinococcus-thermus, chlamydiales, actinobacteria, candidate division TM6 and a small proportion of unclassified bacteria (Lin et al., 2013; Henne et al., 2012). Filamentous fungi, protozoa, virus and helminths are also commonly found (Abe et al., 2011; Lin et al., 2014). The existence of inorganic matter, like corrosion products, clays and sand, can be responsible for changes in biofilm structure, increasing its mechanical cohesion (Melo and Bott, 1997). Biofilms occur usually on surfaces which are in contact with water. So, biofilm formation is common in DWDS. Wingender and Flemming (2004) stated that $95 \%$ of water microorganisms are present in DWDS inside biofilms while only $5 \%$ are floating in the bulk phase.

Although biofilms are the main form of microbial organization in nature, the formation of these structures in DWDS depends of several biotic and abiotic factors, namely environmental factors (temperature and $\mathrm{pH}$ ), concentration of residual disinfectants, nature and concentration of nutrients, hydrodynamic conditions (flow rate, design of network and presence of dead ends), type of pipe materials and their conservation state, type and diversity of microorganisms present and sediment accumulation (Deines et al., 2010; Jang et al., 
2011; Simões and Simões, 2013; Yu et al., 2010). The biofilm formation process occurs in several steps (Fig. 1). According to O'Toole et al. (2000), the biofilm formation process begins with the preconditioning of the pipe surface by organic and inorganic macromolecules that facilitate the bacterial adhesion process. Thereafter, cells can adsorb to the surface reversibly or irreversibly (a). After adhesion, a stage of active biofilm growth occurs by cell replication, EPS production, release of quorum-sensing (QS) molecules and exchange of substances between the biofilm and the bulk (b and $c$ ). As subsequent steps, Codony et al. (2005) proposed that occurrence of biofilm dispersion and formation/colonization in other clean areas can take place after biofilm detachment from pipes walls, as depicted in Fig. 1(d)-(f). The amount of a biofilm in a given system, after a certain period of time, depends on a dynamic biofilm formation process, which has been defined as the balance between bacterial attachment from the planktonic phase, bacterial growth within the biofilm and dynamic detachment from the surface (Stoodley et al., 1999). When the balance is null, the biofilm is said to have reached a steadystate. The final amount of biofilm in that state, which can be assessed by cell counts or biomass determination, is directly related to its formation potential in the system (van der Kooij, 1999). Hydrodynamics have an utmost role in biofilm development and in determining its stability (Bott, 1993). The flow rate affects biofilm development by interfering with several phenomena, namely: nutrients transport, bacterial adhesion, biofilm growth and detachment (Characklis and Marshall, 1990). When the flow velocity is low there is a high resistance to mass transfer (nutrients, oxygen, etc.) from the bulk fluid to the microorganisms embedded in biofilms, impairing sessile cell growth. On the other hand, high flow velocity causes high turbulence of the fluid bulk. It means that the mass transfer phenomena are enhanced, improving also the biofilm growth. However, high velocity also causes high shear forces that can be responsible for higher biofilm erosion and detachment; accordingly it may cause a decrease of biofilm mass on surfaces. Therefore, apart from others factors, studies on the effects of hydrodynamic conditions are also very important to understand biofilm formation in DWDS. However, the hydrodynamic conditions (flow rate, velocity, residence time, shear stress) are dependent of the geometry of

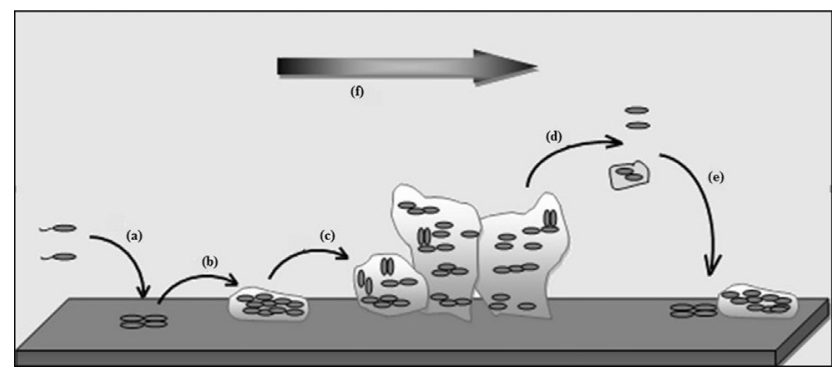

Fig. 1 - - Biofilm formation, detachment and recolonization in DWDS. (a) Attachment, (b) initiation, formation of colonies, starting of EPS production, (c) biofilm maturation, (d) biofilm dissolution, (e) biofilm recolonization of DWDS pipes influenced by the water flow (f). Based on Codony et al. (2005). each biofilm reactor. The dimensionless Reynolds number (Re), in fluid mechanics, is defined as the ratio of inertial forces to viscous forces and is used to describe the flow conditions of a fluid (laminar, transition and turbulent flow). Its calculation is dependent of the reactor flow geometry. Also, the definition of laminar and turbulent flow regimes varies according to the system used. The Re number for the flow in a pipe or tube can be defined by Eqs. (1) and (2) where $D_{H}$ is the hydraulic diameter of the pipe $(\mathrm{m}), \rho$ is the fluid density $\left(\mathrm{kg} \mathrm{m}^{-3}\right), v$ is the flow velocity $\left(\mathrm{m} \mathrm{s}^{-1}\right), \mu$ is the dynamic viscosity of fluid $\left(\mathrm{N} \mathrm{s} \mathrm{m}^{-2}\right), \mathrm{A}$ is the pipe cross sectional area $\left(\mathrm{m}^{2}\right)$ and $\mathrm{P}$ is the wetted perimeter $(\mathrm{m})$. The wetted perimeter for a pipe is the perimeter of the pipe wall that is in contact with the water flow.

$R e_{\text {pipe }}=\frac{\rho v D_{H}}{\mu}$

$D_{H}=\frac{4 A}{P}$

In cylindrical pipes, $R e<2300,2300<R e<4000, R e>4000$, correspond to laminar, transition and turbulent flow conditions, respectively. The Re number for a stirred tank is defined by the Eq. (3) where $N$ is the rotational velocity and $D$ is the diameter of agitator. For an agitation situation the laminar flow is considered when $R e<10$ and turbulent flow for $R e>10^{4}$ (Pérez et al., 2006).

$R e_{\text {stirred tank }}=\frac{N D^{2} \rho}{\mu}$

One of the major obstacles to study biofilms within DWDS is how to choose a suitable experimental system that mimics the conditions found in real pipe networks. A number of devices have been described in literature for studying biofilms in DWDS. Therefore, the aim of this review is to provide an overview on old and well described and reviewed biofilm reactors as well as on new or more recently developed reactors that not have been reviewed together yet. The diverse devices are described as well as aspects on their limitations and advantages. Also, a brief description on the main applications of reactors in DW biofilm studies and the quantification methods used for DW biofilm characterization is provided. Nevertheless, the complexity of the DWDS microenvironment and even the use of different methodologies and biofilm reactors have led in some cases to ambiguous or not easily comparable results. Most studies assessed only one variable at a time, and apart from notable exceptions, few attempts have been made so far to study their inter-relationships and compare the relative importance of these different factors.

\section{Bench top laboratorial devices}

Several devices were developed to study biofilms autonomously from DWDS. These devices try to mimic the DWDS behavior, allowing testing different conditions and can be fed with tap water or with appropriate medium or enriched water. In fact, these devices are DWDS models used to achieve a diversity of goals. However, they were used mostly in laboratorial experiments. 


\subsection{Annular reactor}

The annular reactor can operate as an open/continuous system and has been used for several decades for the development of biofilms under turbulent flowing environments (Morin and Camper, 1997; Volk and LeChevallier, 1999). It is a simple reactor that mimics the hydrodynamic behavior that biofilms are subjected in real DWDS (Batté et al., 2003a; Keinänen-Toivola et al., 2006). This reactor, also known as Rototorque, is constituted by two cylinders, one static external cylinder that can be of actual pipe materials and other rotating internal cylinder whose speed is controlled by a motor (Chandy and Angles, 2001; Fang et al., 2010; Hosni et al., 2011; Morin and Camper, 1997; Zhou et al., 2009). The inner cylinder supports some coupons used to sample the biofilm (Fig. 2). The rotation of the inner cylinder is controlled in order to define the desired shear stress. The relationship between shear forces, the cylinder diameter and the rotational speed is provided in Table 1 . However, the equations are a gross simplification of the annular reactor shear stress determination, since its calculation for this particular system is quite complex.

The shear stress usually described as characteristic of DWDS pipes is $0.25 \mathrm{~N} \mathrm{~m}^{-2}$ that is equivalent to $0.3 \mathrm{~m} \mathrm{~s}^{-1}$ in a $100 \mathrm{~mm}$ diameter pipe; these conditions are often reproduced in the annular reactor (Butterfield et al., 2002; Fang et al., 2010; Gagnon et al., 2004, 2005; Jang et al., 2011, 2012; Morin and Camper, 1997; Murphy et al., 2008; Pintar and Slawson, 2003; Szabo et al., 2006). One value of flow velocity that is also often used is $0.6 \mathrm{~m} \mathrm{~s}^{-1}$ (Batté et al., 2003a, 2003b; Sharp et al., 2001). Rand et al. (2007) tested a shear force of $0.68 \mathrm{~N} \mathrm{~m}^{-2}$ to assess the efficiency of chlorine dioxide or chlorine coupled with UV treatment on DW biofilm control. The data shown that, the combination of chlorine dioxide/UV was the most effective strategy against both suspended and attached bacteria. Altman et al. (2009) studied the integration and retention of planktonic pathogen Bacillus cereus in a Pseudomonas fluorescens biofilm under a range of different hydraulic conditions (from 0.15 to $1.5 \mathrm{~N} \mathrm{~m}^{-2}$ or from 50 to $300 \mathrm{rpm}$ ). The authors found that the

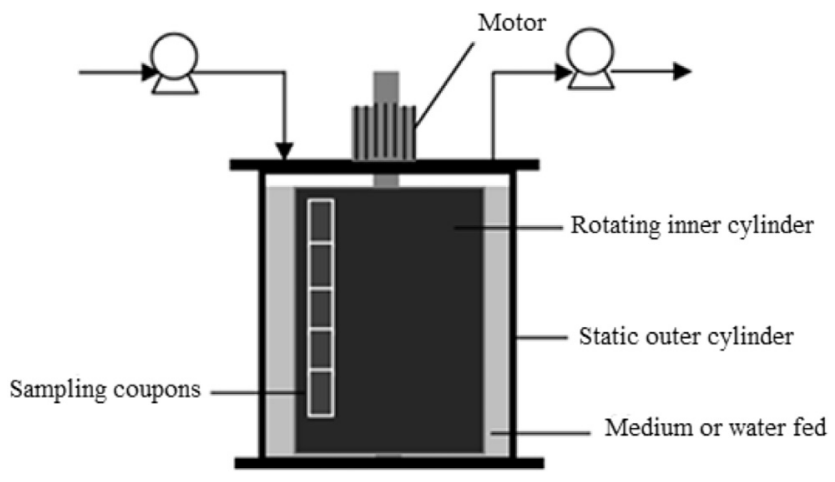

Fig. 2 - Annular reactor, cross-sectional view. The operational mode (batch or continuous) can be controlled by the pumps; the shear stress is controlled by the rotation of the inner cylinder. amount of pathogens detected in the biofilms was higher in the mid-shear range.

This reactor also has been used to study the influence of temperature on biofilm development. Some annular reactors have a jacket allowing working at the desired temperature. Pintar and Slawson (2003) tested different temperatures $(6,12$ and $22^{\circ} \mathrm{C}$ ) and different concentrations of disinfectant residual (chloramination) being the reactor fed with tap water and working at constant rotation speed $(50 \mathrm{rpm})$ providing a shear stress of $0.25 \mathrm{~N} \mathrm{~m}^{-2}$. The results clearly indicate that biofilm development occurs at all examined temperatures, as well as at the selected monochloramine residuals. However, the maintenance of a disinfectant residual had more biofilm inhibitory effects than that of the low temperature. Ndiongue et al. (2005) also studied the effect of temperature $(6,12$ and $18{ }^{\circ} \mathrm{C}$ ) and biodegradable organic matter on biofilm control by chlorine at $92 \mathrm{rpm}$. Overall, the results shown that both temperature and nutrients levels are important factors that must be considered when using free chlorine residual to control DW biofilms.

With the aim to perform different studies and save resources, variations of the conventional annular reactor were developed. An example is the conical annular reactor. A standard annular reactor provides a constant wall shear stress distribution on surfaces, while a conical annular reactor generates a non-uniform distribution of this hydrodynamic strength. Rochex et al. (2008) used a conical annular reactor (CCTR - Conical Couette-Taylor reactor) to develop biofilms at varying shear stresses $(0.055-0.27 \mathrm{~Pa}$ from bottom to top of the reactor) with only one device and provided a useful model for studying the effect of hydrodynamics on biofilms. These authors also evaluated the effects of shear stress on the bacterial biofilm community composition. The results shown that, high shear stresses decreased biofilm diversity and slowed down its maturation, maintaining the characteristics of young biofilms.

The use of annular reactors to study DW biofilm development and control can be advantageous, mainly if the objective of the work is to study the material influence (allows the study of different materials at the same time) or the effect of hydrodynamics. This reactor also allows to take a considerable number of samples for each assay and has an easy sampling process. The control of shear stress and linear velocity is also simple since it is determined by the rotational velocity of the internal cylinder and thereafter it is independent from the water flow rate fed to the reactor. So, the residence time and loading rate can be controlled independently. Nevertheless, as referred above, the description of hydrodynamic equations in annular reactors is complex once the flow on cylindrical surface is not well defined due to the presence of Taylor vortices (Childs, 2011). Therefore, the shear stress is not uniform in all surfaces available for biofilm formation.

\subsection{Concentric cylinder reactor}

The concentric cylinder reactor (CCR) was firstly described and used to study biofilm formation in the dairy industry (Willcock et al., 2000). This reactor allows the simultaneous generation of different shear rates on the same inoculating 
Table 1 - Fluid dynamic equations for DWDS model reactors.

\begin{tabular}{|c|c|c|c|}
\hline Reactor & Equations & Assumptions/observations & References \\
\hline Annular reactor & $\begin{array}{l}\operatorname{Re}=\frac{N \cdot D_{h}^{2} \cdot \rho}{\mu} ; D_{h}=D_{o}-D_{i} \\
f=\frac{0.0791}{R e^{0.25}} \\
\gamma=\frac{f \rho v^{2}}{2}\end{array}$ & $\begin{array}{l}\text { - Gross simplification } \\
\text { - The expressions used are common to } \\
\text { closed pipe flow }\end{array}$ & Altman et al. (2009) \\
\hline CCR & $\begin{array}{l}\operatorname{Re}=\frac{N \cdot D_{h}^{2} \cdot \rho}{\mu} ; D_{h}=D_{o}-D_{i} \\
f=0.158 R e_{A}^{-0.3} \\
\gamma=\frac{f \rho v^{2}}{2}\end{array}$ & $\begin{array}{l}\text { - Fanning factor is adjusted to rotating cylinders } \\
\text { (Nesic et al., 1997) but it still is a gross approach }\end{array}$ & \\
\hline Propella ${ }^{\circledR}$ reactor & $\begin{array}{l}\operatorname{Re}=\frac{\rho \cdot \cdot \cdot D_{h}}{\mu} ; D_{h}=D_{o}-D_{i} \\
f=\frac{0.0791}{R^{0} 0.25} \\
\gamma=\frac{f \rho v^{2}}{2}\end{array}$ & - The flow was not changed by the coupons & \\
\hline $\begin{array}{l}\text { Flow cell reactor; } \\
\text { In situ devices }\end{array}$ & $\begin{array}{l}R e=\frac{\rho \cdot v \cdot D_{h}}{\mu} ; \\
D_{h}=\frac{\pi \cdot D}{2 \cdot \pi} \text { to a semicircular duct } \\
D_{h}=\frac{2 a b}{a+b} \text { to a rectangular duct } \\
f=\frac{0.0791}{R R^{0.25}} \\
\gamma=\frac{f \rho v^{2}}{2}\end{array}$ & $\begin{array}{l}\text { - Flow cell: It is used the expression of Fanning } \\
\text { factor from circular pipes; } \\
\text { - The flow is not changed by the coupons }\end{array}$ & Teodósio et al. (2012) \\
\hline RDR & $\gamma=0.729 r \sqrt{\frac{\mathrm{N}^{3}}{\delta}}$ & $\begin{array}{l}\text { - From Navier-Stokes equations as described } \\
\text { Schlichting (1955) }\end{array}$ & Pelleïeux et al. (2012) \\
\hline CDC reactor & $\begin{array}{l}R e=\frac{N \cdot \alpha \cdot R_{0}^{2} \cdot \rho}{\mu} \\
R e_{\text {trans. }}=\frac{41.3}{(1-\alpha)^{1.5}} \\
f_{\text {turb. }}=\frac{0.0791}{R e^{0.25}} \\
f_{\text {lam. }}=\frac{16}{R e} \\
\gamma=\frac{f \cdot \rho \cdot N^{2} \cdot R_{i} \cdot R_{0}}{2}\end{array}$ & $\begin{array}{l}\text { - Reactor is modeled by two concentric cylinders } \\
\text { - Reynolds equation described by Characklis and } \\
\text { Marshall (1990) to concentric cylinders. }\end{array}$ & Goeres (2006) \\
\hline
\end{tabular}

$a$ and $b$ - Dimensions of the rectangular flow section; $D$ - diameter of the semicircular flow section; $D_{h}-$ hydraulic diameter; $D_{o}-$ outer diameter; $D_{i}$ - inner diameter; $f$ - fanning friction factor; $N$ - rotating speed; $R_{o}$ - outer radius; $R_{i}$ - inner radius; $v$ - fluid velocity; $\alpha$ - ratio of inner to outer cylinder; $\rho$ - fluid density; $\mu$ - dynamic viscosity; $\delta$ - kinematic viscosity; $\gamma$ - shear stress.

population (Willcock et al., 2000), but not with the same water phase since the four chambers are fed independently (Fig. 3). Latter, this reactor was used to study DW biofilms by Rickard et al. (2004), who described the effects of different shear forces on DW biofilms formation and its impacts on the microbial community diversity. This reactor is composed by four rotating cylinder pipes and four stationary cylinder chambers (Fig. 3). The chambers can be feed with tap water and the volume inside the chambers is constant and controlled with the help of external pumps, being the feeding ports different from the outlet and sampling ports. The shear stress is controlled with the rotational velocity and radius of the

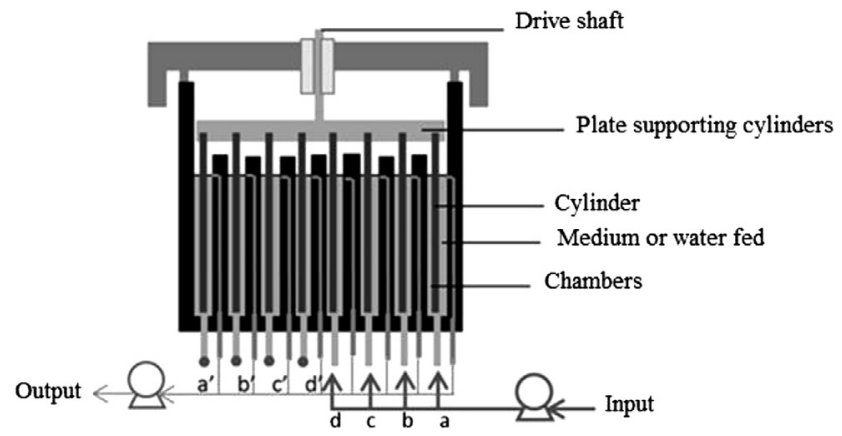

Fig. 3 - Cross-sectional view of the concentric cylinder reactor (CCR), four rotating cylinders interlocked within the four collecting stationary cylinder chambers. $a-d$ are the inlet ports to fed the medium or water corresponding to the same chambers; $a^{\prime}-d^{\prime}$ are the sampling ports in each chamber. cylinders (Table 1). Rickard et al. (2004) used this reactor with cylinders whose diameter was 101, 77, 50 and $26 \mathrm{~mm}$ that corresponds to fluid velocity of $0.26,0.19,0.16$ and $0.12 \mathrm{~m} \mathrm{~s}^{-1}$ and shear rates of 305, 198, 122 and $65 \mathrm{~s}^{-1}$, respectively. The rotational speed of cylinders was kept constant during all the work (43 rpm), while the shear force varied with the radius of the rotating surface. The fluid velocity profiles were determined on the basis of computational fluid dynamics and from each fluid velocity profile, shear rates were calculated. The results demonstrated that shear rates affect biofilm diversity as well as the relative proportions of aggregating bacteria. An inverse relationship between shear rate and biofilm diversity was found and the proportions of aggregating bacteria in biofilms also change in relation to shear rates. The authors suggested that it is likely that such cell-cell interactions aid in the integration of bacteria in flowing environments.

This reactor is interesting to study simultaneously the effects of different shear stresses on DW biofilm, allowing to mimic what happens with DWDS since along the distribution system there are variations on water flow velocity. However, it only allows studying one material for each assay and the sampling process is not very easy, since it is necessary the harvesting of biofilm samples from the cylinder surface.

\section{3. $\quad$ Propella ${ }^{\circledR}$ reactor}

The Propella ${ }^{\circledR}$ reactor was already used by several authors for DW biofilms studies (Dailloux et al., 2003; Gosselin et al., 2013; Lehtola et al., 2006, 2007; Rubulis and Juhna, 2007; Simões et al., 2012; Torvinen et al., 2007). It consists of two concentric cylinders in which the propeller pushes the liquid down 
through the inner tube and then up through the annular section between both cylinders (Fig. 4). It is a perfectly mixed reactor and the fluid velocity, hydraulic residence time and the flow rate are controlled by the rotation speed of the propeller (Table 1). Coupons are usually located in the outer tube facilitating the sampling process and in some cases the removal of coupons does not change the flow conditions.

The ability of this reactor to simulate the process conditions commonly found in real DWDS makes it attractive for diverse studies. Dailloux et al. (2003) used a Propella ${ }^{\circledR}$ reactor with $2.08 \mathrm{~L}$ of volume (with high-density polyethylene (HDPE) coupons), water velocity of $0.2 \mathrm{~m} \mathrm{~s}^{-1}$, fed continuously with tap water $\left(83.5 \mathrm{~mL} \mathrm{~h}^{-1}\right)$ and inoculated with Mycobacteria xenopi in order to evaluate the ability of this bacterium to colonize the experimental DW biofilms. The authors verified that biofilms may be reservoirs for the survival of $M$. xenopi and contributors to the continuous contamination of DW by erosion processes. Lehtola et al. (2006) used Mycobacterium avium and a 2.3 L Propella ${ }^{\circledR}$ reactor with polyvinyl chloride (PVC) coupons, working at a flow rate of $183 \mathrm{~mL} \mathrm{~min}^{-1}(R e=15000$, retention time $=12.6 \mathrm{~h}$ ). And they concluded that this bacterium is able to survive and grow in DW biofilms and possibly transmitted via DW. The same reactor and the same conditions were used in other study to assess the survival of M. avium, Legionella pneumophila and Escherichia coli in DW biofilms under highshear turbulent flow conditions (Lehtola et al., 2007). This study clearly proved that pathogenic bacteria entering DWDS can survive in biofilms for at least several weeks, even under conditions of high-shear turbulent flow, and may be a risk to water consumers. This reactor also was used to study the influence of phosphorus concentration on biofilm development (Rubulis and Juhna, 2007; Torvinen et al., 2007). Rubulis and Juhna (2007) used the Propella ${ }^{\circledR}$ reactor with PVC coupons fed with DW, at $0.25 \mathrm{~m} \mathrm{~s}^{-1}$ and retention time of $24 \mathrm{~h}$, aiming to assess the possibility to prevent biofilm formation by the removal of phosphorus. Those experiments showed that removal of phosphorus to very low levels $\left(<1 \mu \mathrm{g} \mathrm{L}^{-1}\right)$ was not an efficient strategy to eliminate bacterial regrowth and biofilm formation in DWDS. Torvinen et al. (2007) studied the

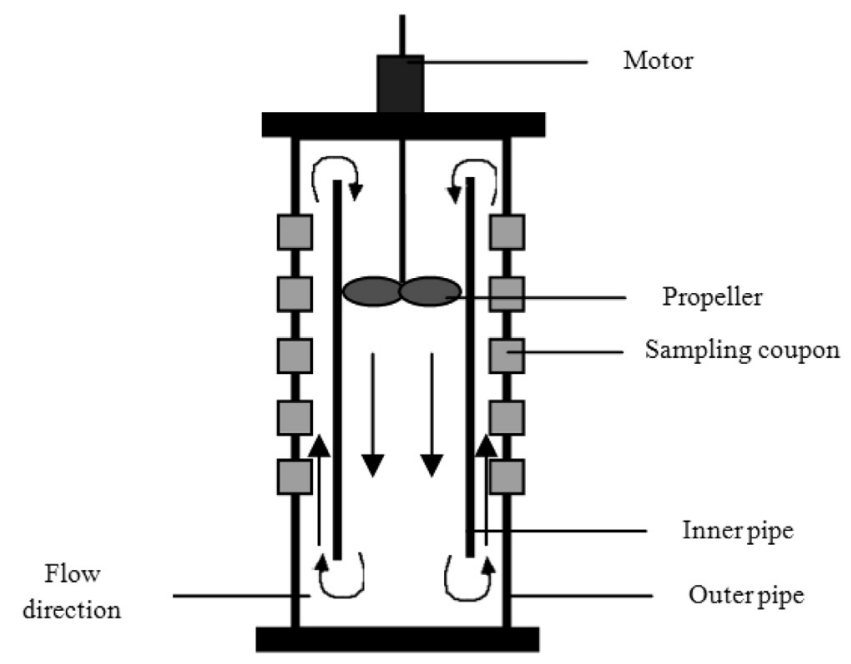

Fig. 4 - Propella ${ }^{\circledR}$ reactor, cross-sectional view. Flow direction is represented by the arrows.

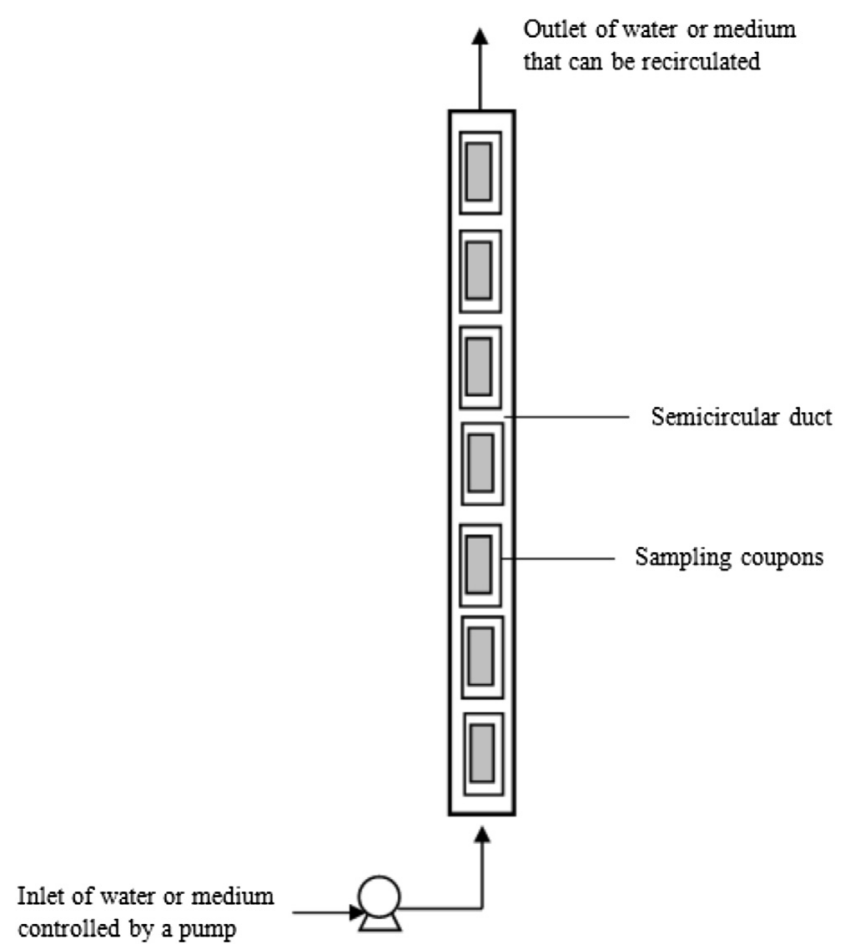

Fig. 5 - Scheme of the flow cell system. The fed can be provided from tap or from reservoirs, the biofilm is formed on the removable coupons and the flow is controlled by external pumps.

influence of low phosphorus concentration, flow rate and temperature on the survival of $\mathrm{M}$. avium in DW biofilms using a Propella ${ }^{\circledR}$ reactor with PVC coupons $\left(185 \mathrm{~mL} \mathrm{~h}^{-1} ; 0.24 \mathrm{~m} \mathrm{~s}^{-1}\right.$; $\mathrm{Re}=15000 ; 12.4 \mathrm{~h}$ of retention time). The authors concluded that temperature is a more important factor than the availability of nutrients, particularly phosphorus, on the survival of slow growing M. avium in DW biofilms. On the other hand, an increase in water flow velocity had no effects on the survival of M. avium, although it increased biofilm productivity.

\subsection{Flow cell system}

The flow cell system consists in a duct segment where removable coupons are inserted in the inner wall, whose allows the biofilm sampling over time. But, this system may present different configurations. The flow cell reactor can be a semicircular duct with some coupons (only the upper face contacts with water) located on the flat wall and the flow pass-through the duct from the bottom to top (Fig. 5). Another flow cell configuration can be a parallel plate flow cell reactor, which consists in a rectangular flow channel with small removable coupons inside, to monitor biofilm formation (Huang et al., 1992). Usually, the flow cell reactor is provided by a feed/fresh water reservoir and the temperature can be controlled externally. The flow is recirculated and the sampling process does not stop the flow because outlet ports are located in the curved wall between two removal coupons, allowing the deviation of flow (Manuel et al., 2007; Simões et al., 2006, 2012). Therefore, this system also allows 
mimicking the DWDS conditions, since it is a versatile system that allows periodical sampling, without stopping the flow, and the flow velocity can be controlled by an external pump. However, the boundary of sampling coupons can change the water flow, which can affect biofilm development. Flow cell reactors can be used to monitor biofilm development and behavior face to different control treatments and also to test the influence of different materials and hydrodynamic conditions on biofilm formation. This reactor also can be used as an in situ device, acting as a bypass in DWDS (Bragança et al., 2007). As example, Simões et al. (2006) used the flow cell reactor to monitor biofilms exposed to different operational conditions. The flow cell reactor was fed with tap water without chlorine, previously removed with activated carbon filters. The influence of diverse conditions on biofilm formation were studied, namely the turbulent $\left(4000 \mathrm{~L} \mathrm{~h}^{-1}, \mathrm{Re}=11000\right)$ and laminar (73 $\mathrm{L} \mathrm{h}^{-1}, \mathrm{Re}=2000$ ) flow, the presence and absence of nutrients (C, P and N) and the type of surface materials, stainless steel (SS) and PVC. This study demonstrated that biofilm productivity increased due to the addition of nutrients to water, being this parameter the most significant in biofilm formation. The second most relevant aspect influencing biofilm formation was the use of turbulent flow conditions instead of laminar hydrodynamic flow. The selection of a pipe surface affected biofilm formation to a less extent, with PVC supporting more biofilm than SS.

Manuel et al. (2007) studied the influence of different materials on biofilm development and the effects of the flow and non-flow regimes on the growth of both attached and suspended bacteria using a flow cell reactor. The reactor was fed with tap water at $15.1 \mathrm{~mL} \mathrm{~d}^{-1}$ with different Re numbers $(5000$ and 8293). Microbiological analysis showed that the support material did not affect significantly biofilm growth. However, operating under continuous flow $(0.8-1.9 \mathrm{~Pa})$ or stagnant water had a significant effect on biofilm formation: in stagnant water the biofilm grew to a less extent. The same authors assessed how hydraulic conditions (stagnation or flushing) can affect the biological stability of biofilms and evaluated the relationship between the stability and the microbial composition of biofilms using a flow cell reactor. Continuous turbulent $\left(R e=4900,6 \mathrm{~L} \mathrm{~min}^{-1}\right)$ and laminar $\left(R e=810,1 \mathrm{~L} \mathrm{~min}^{-1}\right)$ flow regimes were used and biofilm formation was monitored for 20 days. Afterward, the system was subjected to unsteady hydraulic conditions (Manuel et al., 2010). Independently of the flow regime under which the biofilm was formed, stagnation promoted bacterial accumulation, either as attached or suspended forms, which were carried away in higher numbers when flow was re-started, thereby compromising the biological quality of the water. In all cases, Betaproteobacteria was the dominant phylogenetic group, although Gamma and Alpha subclasses were also present. These results suggest that special attention should be given to the biological quality of DW when consumption is subjected to strong variable demands (Manuel et al., 2010).

\subsection{Rotating disc reactor}

The rotating disc reactor ( $R D R$ ) consists in a tank with a rotating disc that is submerged in water (Fig. 6). The disc holds several coupons distributed concentrically and, as happens with the CCR, the shear forces depend on the rotational speed and on the diameter where coupons are allocated (Table 1) (Abe et al., 2011, 2012; Pelleïeux et al., 2012).

Abe et al. (2011) used this type of reactor to assess the elasticity and physico-chemical properties of DW biofilms in different stages of growth at constant hydrodynamic conditions (hydraulic shear stress of $0.12 \mathrm{~Pa}$ and shear rate of $120 \mathrm{~s}^{-1}$ ). DW biofilms showed a spatially discontinuous and heterogenous distribution comprising an extensive network of filamentous fungi in which biofilm aggregates were embedded. These results suggest that the DW biofilms were composed of a soft top layer and a basal layer with significant high elastic modulus values, falling in the range of fungal elasticity. The same authors used the RDR to study the cohesiveness and hydrodynamic properties of young DW biofilms (Abe et al., 2012). In this study the reactor was operated over three months at shear rates of 120, 175 and $230 \mathrm{~s}^{-1}$ (hydraulic shear stress of $0.120,0.175$ and $0.230 \mathrm{~Pa}$, respectively), according to the location radius of each coupon. The results highlighted DW biofilm mechanical behavior depending on cohesiveness strength profile; the increasing of shear stress promoted a layer by layer (stratified structure) biofilm removal; and the detachment shear stress was weakly impacted by the biofilm age (from 4 to 12 weeks) and the hydrodynamic formation conditions (from 0.120 to $0.230 \mathrm{~Pa}$ ). Pelleieux et al. (2012) studied the accumulation of phages on DW biofilms at different shear rates (from 450 to $1640 \mathrm{~s}^{-1}$ ) and under flow/non-flow conditions. All shear rates studied did not cause differences in the levels of virus and bacteria. However, convective diffusion (flow conditions) led to an increase of about $1 \mathrm{log}$ in virus concentration on surfaces

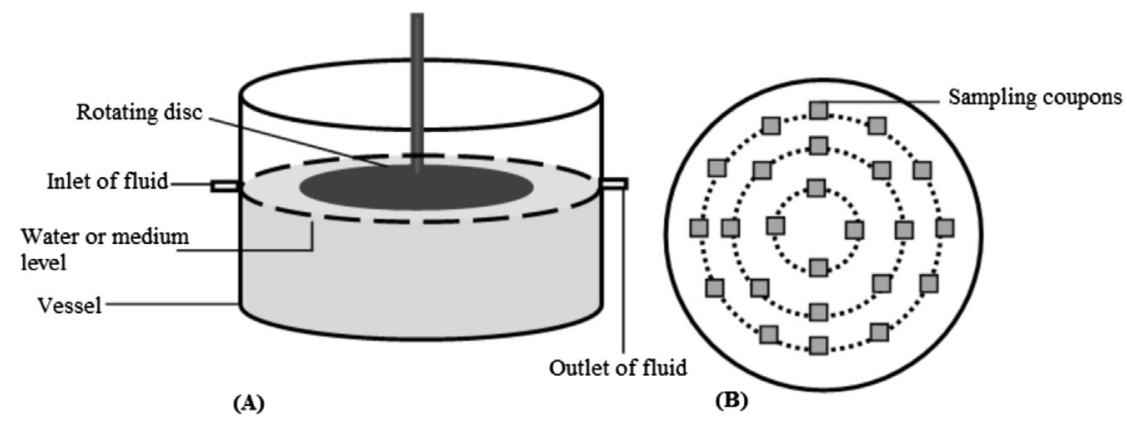

Fig. 6 - (A) Rotating disc reactor (RDR), the inlet and outlet of fluid can be controlled with a pump. (B) Scheme of the disposal of removable coupons in the disc. 
compared to the levels of the pseudo-steady-state reached during the Brownian diffusion (non-flow conditions). The presence and behavior (survival) of some pathogens (L. pneumophila, Pseudomonas aeruginosa, Klebsiella pneumoniae and Flavobacterium sp.) in DW biofilms also was studied by Murga

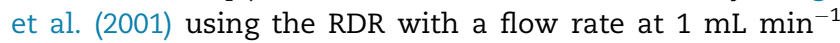
(residence time $6.7 \mathrm{~h}$ ). It was found that, although unable to replicate in the absence of protozoa, L. pneumophila was able to persist in DW biofilms.

In $\mathrm{RDR}$, as the entire disc rotates in the water, each radial position experiences a varying hydraulic shear stress, which enables the simultaneous formation of biofilms under different hydrodynamic conditions while keeping all the other conditions constant.

\subsection{CDC biofilm reactor}

The Centers for Disease Control (CDC) biofilm reactor, also known as CBR, was already used as a DWDS model. In this reactor the coupon holders are supported by a ported lid with each holder containing usually 3 coupons (Fig. 7). The lid with the holders is mounted in a vessel and the agitation is ensured by placing the reactor on a controlled stirrer plate, providing a constant rotation of the baffle (Armbruster et al., 2012; Goeres et al., 2005; Morrow et al., 2008; Park et al., 2012; Park and Hu, 2010). This reactor was used for different applications. Park and $\mathrm{Hu}$ (2010) used it to assess the effects of a reverse osmosis water pre-treatment on biofilm development in DWDS. However, this pre-treatment was unable to produce biologically stable water, although it had lower growth potential than the tap water produced from conventional water treatment. Armbruster et al. (2012) used a CDC biofilm reactor to develop a stable, repeatable, DW multispecies biofilm model (Sphingomonas paucimobilis, Methylobacterium sp., Delftia acidovorans, and Mycobacterium mucogenicum) to investigate the interaction of the opportunistic pathogen $\mathrm{M}$. mucogenicum with other DW species, and determined the efficacy of monochloramine as a disinfectant (batch and continuous flow disinfection) against two weeks old biofilms. The reactor

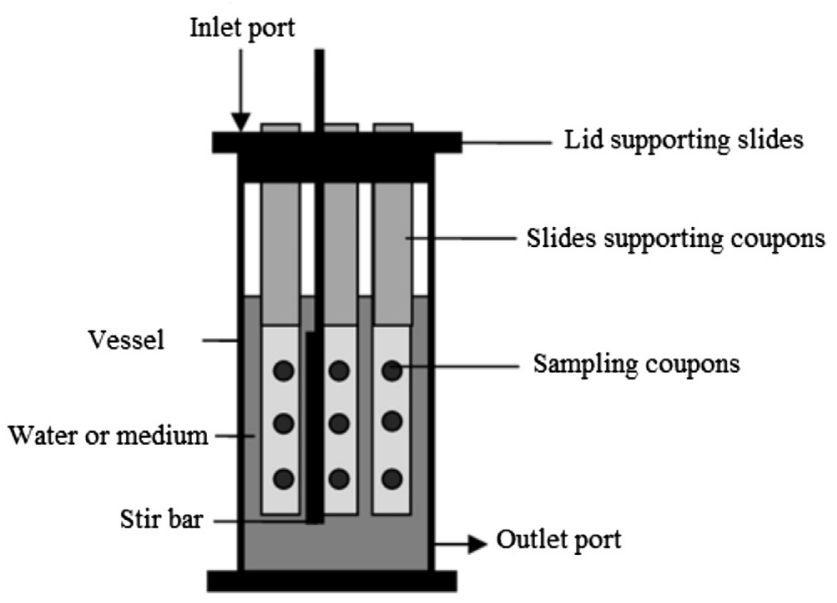

Fig. 7 - Center for disease control (CDC) biofilm reactor, cross-sectional view. The flow is controlled by external pumps. operated under batch mode ( $24 \mathrm{~h}, 100 \mathrm{rpm}$ ) followed by continuous flow conditions $\left(2.5 \mathrm{~mL} \mathrm{~min}^{-1}, 100 \mathrm{rpm}, 140 \mathrm{~min}\right.$ residence time, $13 \mathrm{~d}$ ). Biofilms persisted in $1 \mathrm{mg} \mathrm{L}^{-1}$ monochloramine over $24 \mathrm{~h}$ but detached bacteria suspended in DW were reduced. Although M. mucogenicum preferentially resided in the biofilm, disinfectant exposure caused release of viable M. mucogenicum from the biofilm into the water. DW biofilms were more tolerant to continuous flow disinfection, which mimicked conditions found in distribution systems more closely than batch disinfection. Morrow et al. (2008) used this device to investigate the impact of fluid shear on Bacillus spores association with biofilm conditioned surfaces in DWDS and the subsequent decontamination with chlorine and monochloramine. Biofilm associated spores required 5- to 10fold higher disinfectant concentrations to observe the same reduction of viable spores as in suspension. Traditional chemical disinfection with monochloramine and chlorine was an inappropriate strategy for decontamination of Bacillus spores from treated water systems. These authors rationalized the selection of the CDC as DWDS model attending to the possibility to control fluid shear on coupons surface (Morrow et al., 2008; Park and Hu, 2010).

\subsection{Other bench top devices}

Other laboratorial devices were developed to allow a better study of DW biofilm formation and control under specific conditions, in order to fill the gap on the limitations of existent reactors.

\subsection{1. $\quad$ Microtiter plates}

The microtiter plates are nowadays the most frequently used reactor system for studying biofilm formation. These can be used as a rapid and simple method to screen simultaneously the effect of high numbers of different parameters on biofilm formation (Simões et al., 2007, 2010a, 2011). However, these reactors, contrary to those previously described are strictly laboratorial biofilm systems and have low similarity to a real DWDS. Simões et al. (2010a) used this device to study the adhesion and biofilm formation on polystyrene by DW isolated bacteria (Acinetobacter calcoaceticus, Burkholderia cepacia, Methylobacterium sp., M. mucogenicum, Sphingomonas capsulata and Staphylococcus sp.). The overall results indicate that initial adhesion did not predict the ability of the tested bacteria to form a mature biofilm, suggesting that other events (e.g. phenotypic and genetic switching and the production of EPS) may play a significant role in biofilm formation and differentiation. In other studies, Simões et al. $(2007,2010 b)$ used microtiter plates to assess biofilm interactions between DW isolated bacteria and the influence of bacterial diversity on biofilm resistance to disinfection. In the first study, the results shown that the parameters assessed by planktonic studies (growth rates, motility, production of quorum-sensing inhibitors) did not allow prediction and generalization of the exact mechanism regulating dual-species biofilm formation. Other cell-cell events, such as intergeneric coaggregation, may play a significant role in the formation and interspecies interactions in DW biofilms (Simões et al., 2007, 2008). Moreover, it was possible to identify synergistic, antagonistic, and neutral interactions between DW bacterial biofilms. The other 
study allowed to conclude that the bacterial diversity and their interactions may enhance biofilm resistance to disinfection. The same device was also used by Simões et al. (2011) to investigate the effects of metabolite molecules produced by these bacteria on their single and multispecies biofilms. This study allowed the identification of bacterial species which have biocontrol potential (M. mucogenicum) or have a significant role in development and maintenance of the DW consortium (A. calcoaceticus and B. cepacia). These studies proposed that the elucidation of the mechanisms by which diverse species survive and interact in DW biofilm communities may allow the identification of new biofilm control strategies.

Gião et al. (2011) used this device to evaluate the interaction of L. pneumophila and Helicobacter pylori with bacterial species isolated from DW biofilms and to study the influence of different autochthonous microorganisms on the incorporation and survival of these two pathogens in biofilms. Mycobacterium chelonae (pathogen commonly found in DWDS) seems to have a positive effect on the cultivability of both pathogens and seems to play an important role in the survival and control of these two pathogens in DW biofilms. This work also suggests that the presence of some microorganisms can decrease the cultivability of L. pneumophila but not the viability, which indicates that the presence of autochthonous microorganisms can lead to misleading results when the safety of water is assessed by cultivability-based methods alone.

This reactor has the obvious advantage of allowing highthroughput analysis, some of those can be non-invasive using microscopy (Bridier et al., 2013). It needs small space to operate and the control of environmental conditions is easy. However, the limitations to reproduce the conditions found in a DWDS are significant. In fact, microtiter plates are not flow through systems. These can only operate under batch or fed-batch conditions and only low hydrodynamic shear stress can be reproduced.

\subsubsection{Flow chamber}

The flow chamber is a simple device already used in DW biofilm studies. This allows a direct non-invasive observation of biofilm formation using microscopy. Paris et al. (2007) used four flow chambers fed in parallel with tap water and coupled to an inverted microscope to study the effects of different shear rates $\left(34.9,74.8,142.5\right.$ and $194.5 \mathrm{~s}^{-1}$ ) on biofilm development and structure. During the first stage of biofilm formation, bacterial accumulation was a function of the wall shear rate: the higher the wall shear rate, the faster the bacterial deposition. After 50 days, surface coverage was more or less identical for all wall shear rates, suggesting that biofilm bacterial density cannot be controlled using hydrodynamics. However, the spatial distribution of the biofilm was clearly different. Under low wall shear rate, aggregates were composed of bacterial cells able to "vibrate" independently on the surface, whereas, under a high wall shear rate, aggregates were more cohesive. The same authors (Paris et al., 2009) used the same experimental setup described in the previous study with DW biofilms. The authors examined biofilms with two model particles recognized as hard (polystyrene) and soft particles (E. coli) in order to investigate the distribution and persistence of these allochthonous particles inoculated in DW flow chambers at various wall shear rates $\left(70-460 \mathrm{~s}^{-1}\right)$ in biofilms with different ages (from 6 to 10 months old). The study showed that biofilm age (e.g. bacterial biofilm density and properties) and convective-diffusion governed the particle accumulation: older biofilms and higher wall shear rates both increased the velocity and the amount of particle deposition on the DW biofilm.

\subsubsection{Reactors with glass beads}

Bauman et al. (2009) described another device, a reactor containing glass beads, where the DW biofilms were developed and their ability to retain $E$. coli was analyzed. The study concluded that this engineered biofilm systems may be considered as a relevant device to capture pathogens from the bulk flow for monitoring purposes. So, it can contribute to improve the general insights into interactions between pathogens and DW biofilms. Codony et al. (2005) and Morato et al. (2005) used a packed-bed biofilm reactor filled with glass beads to monitor DW biofilm development by removing the biofilm attached to these beads for off-line analysis. Lehtola et al. (2002) used a PVC chamber covered with aluminum foil containing PVC slides to study the effects of low concentration of phosphorus in biofilm development. The results showed that the availability of phosphorus regulated not only the development rate of biofilms but also microbial numbers during steady-state.

\subsubsection{Chemostat}

A two-stage chemostat model system was used to evaluate the persistence of $H$. pylori in DW biofilms (Gião et al., 2008). For biofilm formation, the chemostats were fed with filtersterilized tap water at $50 \mathrm{~mL} \mathrm{~h}^{-1}$. These vessels contained PVC coupons used to sample the biofilm overtime. The influence of three parameters (low carbon concentrations, shear stress and temperature) on the persistence and cultivability of H. pylori in DW biofilms was studied. The results shown that shear stress did not influence negatively the numbers of $H$. pylori cells attached, suggesting that the autochthonous DW bacteria have an important role in retaining this pathogen in the sessile community.

Teng et al. (2008) used a simple system where coupons were submerged in a glass bottle fed with tap water. The cast iron coupons were removed at different times and after each sample the water was displaced with new tap water or sterile tap water to simulate the intermittent water flow environment in pipes. The aim of the study was to assess the effects of biofilms on cast iron pipe corrosion over time in DWDS, namely the characterization of corrosion scales and DW biofilm community structure. The authors demonstrated that the biofilm can greatly affect element composition and crystalline phase of corrosion scales. Also, biofilms accelerated corrosion in the first $7 \mathrm{~d}$, but inhibited corrosion thereafter, which was due to the changes in the biofilm microbial diversity (presence of iron bacteria and iron reducing bacteria).

\subsubsection{Glass ring column}

A glass ring column device, similar to the flow cell system, was used to assess the influence of biofilms on Fe and Mn deposition in DWDS (Ginige et al., 2011). The column was feed with 
tap water inoculated with DW microorganisms, namely $P$. fluorescens and Spirillum spp. The reactor was allowed to operate continuously for 4.5 months at a flow rate of $0.42 \mathrm{~mL} \mathrm{~min}^{-1}$ and a recirculation rate of 667 , the reactor resembled a completely mixed flow-through configuration. This study addressed the contribution of biofilms to discolored water incidents. Biofilms facilitated the deposition of Fe and Mn on pipe walls, an increase in biofilm activity was associated with an increase in Fe and $\mathrm{Mn}$ accumulation. So, reducing biofilm accumulation should be considered along with other strategies, such as removal of Fe and Mn via water treatment to better manage discolored water events.

van der Kooij et al. (1995) designed a device based on two principles: the hydraulic conditions should resemble those in pipes of real systems, and should have a simple construction and use. The device consisted in a vertically placed glass column, containing 40 glass or Teflon cylinders for cell adhesion. The water flowed downward through the column (4.6 $\mathrm{L} \mathrm{min}^{-1}, 0.2 \mathrm{~m} \mathrm{~s}^{-1}$ ) coming in contact with the inner and the outer surface of the cylinders. With this system, the authors assessed the effects of support material, water type and nutrients on the rate and extent of biomass accumulation. The results showed that the material type (glass and Teflon) and the cylinder position had minor or insignificant effects on biomass accumulation. On the other hand, biofilm formation was strongly enhanced by low concentrations of easily available substrates, such as acetate.

\subsubsection{Pedersen device}

The Pedersen device is used coupled to other bench top devices, as flow cells, and it was used to study biofilms in flowing-water systems (Pedersen, 1982). To build this device, microscope cover slips were fitted into acrylic plastic holders forming two parallel test piles, each with room for 19 slips. The test piles were placed in flow cells, and in order to separate the flow at the inlet of the reactor three diffusers with different hole patterns were used. These diffusers were located in both sides of the reactor, being possible to change the flow direction. Flow stabilizers, which were identical to test piles, were used to establish a laminar flow between the slips. The sampling process in this device was done at fixed times taking out a desired number of slips for off-line analysis. Normally, one sample consisted of two slips, one from each of the two parallel piles. The sampled slips were replaced with new ones in order to maintain the flow conditions (Pedersen, 1982).

\subsubsection{Loop with biofilm test-plug module}

Boe-Hansen et al. (2003) developed a loop with biofilm testplug module in order to simulate DWDS conditions and to produce a large number of biofilm samples grown under comparable conditions. This device was constituted by two identical loops connected in series and in each loop there was an adjustable centrifugal pump to recycle the water. The recycle-flow rate was controlled by a needle valve installed immediately downstream the pump. Both loops contained two strings of biofilm test-plug modules made from square pipes, each string consisted of a row of 5 biofilm test-plug modules, each with 7 test-plugs. To prevent turbulence induced by pumps, valves and bends and to stabilize the flow inside the modules, a $2 \mathrm{~m}$ square pipe was inserted just upstream of the test plug modules. This construction should guarantee that the velocity distribution was identical from cross-section to cross-section, and that all test plugs within a loop were exposed to identical hydraulic conditions. Using this device, Boe-Hansen et al. (2003) monitored biofilm formation and activity in DWDS under oligotrophic conditions. The purpose of this study was to test 11 different microbial methods for monitoring biofilm in DW, at low nutrient conditions. The methods used allowed biofilm characterization in terms of biomass quantification, metabolic activity measurement, structure visualization and microbial diversity profiling. The model distribution system was continuously fed with DW from a municipal distribution network (retention time $2 \mathrm{~h}$, flow velocity $0.07 \mathrm{~m} \mathrm{~s}^{-1}$ ). The model distribution system and the biofilm sampling modules used in this study provided an easy access to a large number of biofilm samples. The system allowed biofilms to be grown under controlled conditions comparable to those prevalent in the DWDS. The retention time, the flow rate and temperature were independently controlled in the system, and furthermore it allowed chemicals or specific microorganisms to be added.

\section{In situ application devices}

The in situ devices were developed to study and monitor DW biofilms in pilot and real DWDS. These devices are usually placed as a by-pass or directly connected to a DWDS. Some of described bench top laboratorial devices, namely flow cells, annular reactor and Propella have been used as in situ devices as well (Wilks and Keevil, 2003; Gagnon et al., 2005; Bragança et al., 2007).

\subsection{Robbins device}

The Robbins device is one of the mostly used to study biofilm behavior in situ in real and pilot scale DWDS. The Robbins device is a pipe with several threaded holes (Fig. 8). Some screws with coupons mounted on the front side are placed in these holes (Manz et al., 1993; Sly et al., 1990). The coupons are aligned parallel to the water flow and can be removed independently (Manz et al., 1993).

As referred previously, the Robbins device can be applied directly to real DWDS. Sly et al. (1990) studied the manganese deposition in a DWDS in the Gold Coast (Australia). The results showed that manganese (bulk concentration of $0.05 \mathrm{mg} \mathrm{L}^{-1}$ ) deposition occurred by chemical and microbial action, although the chemical deposition rate was much higher than microbial deposition. Manz et al. (1993) also used the Robbins device to test biofilm formation on glass slides in the Norrvatten (Sweden) DWDS at a distance of $30 \mathrm{~km}$ from the waterworks. These authors found that surface-attached cells are more active than free-living equivalents. Also, the authors found that microcolonies in very early stages of development consisted of mixed populations.

As the Robbins device is responsible for significant changes of the water flow on the slides, several authors developed a modified Robbins device (MRD). Nickel et al. (1985) developed an MRD to assess the degree of resistance of biofilm bacteria to 


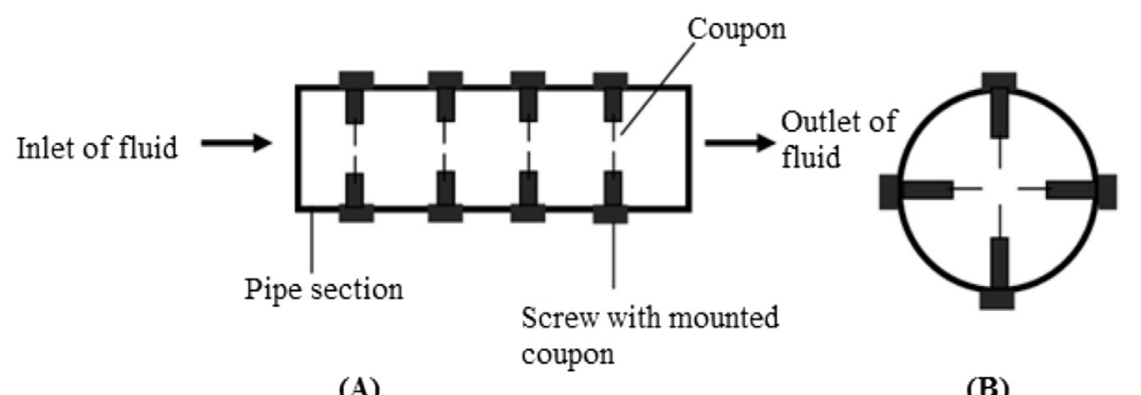

(A) coupon

(B)

Fig. 8 - Robbins device. (A) Longitudinal section; (B) cross-sectional view.

antibiotics in catheter material. This new device consisted in a pipe with 25 spaced sampling ports attached to sampling plugs flushed with the inner surface, without disturbing the flow characteristics. Kalmbach et al. (1997) used the MDR in a DWDS of Berlin (Germany) with a flow rate near of $6 \mathrm{~L} \mathrm{~h}^{-1}$ to investigate the metabolic activity and the phylogenetic affiliation of single adherent bacteria during colonization and biofilm formation in DW. The authors found that respiratory activity of adherent bacteria decreased continuously during the early stages of biofilm formation. Carter et al. (2000) used this device in the Milford (USA) DWDS using a flow rate near of $0.4 \mathrm{~L} \mathrm{~min}^{-1}$. The main goal of this study was to identify relationships among heterotrophic bacteria and standard physical and chemical water quality parameters. A relationship was found particularly to cultivability counts on R2A medium. Silvestry-Rodriguez et al. (2008) also used this device to study biofilm control in an experimental plant using water from Tucson (USA) DWDS, operating at $0.4 \mathrm{~L} \mathrm{~h}^{-1}$. PVC and stainless steel were used as biofilm formation substrate, however, no significant inactivation was observed on both surfaces when treated with silver at $100 \mu \mathrm{g} \mathrm{L}^{-1}$.

Latter, Kerr et al. (2000) developed the newly modified Robbins device (nMRD) that consisted in an MRD adapted to form two separate halves, being possible to take it apart and to clean it. This new device was constructed from Perspex and the two separate halves were held together by thirty screws, and the whole device had Perspex connectors at both ends to which the tubes were attached. This study was performed in order to investigate the reproducibility of attachment and whether there was a statistical significant gradient of adhesion along the 25 sampling ports of the nMRD. No significant difference occurred between pairs of nMRDs that were run in parallel, however, there was a significant difference between different batches of bacteria. It also was observed that the position of the sample disc influenced bacterial adhesion. Other variation of the Robbins device was presented by Jass et al. (1995) that used a chemostat-coupled MRD. The association of a chemostat and an MRD provides a large number of sample surfaces for monitoring biofilm formation and control over extended periods of time. These authors proposed that this device can be successfully used for studying bacterial adhesion and biofilm formation in tubular devices.

\subsection{Pennine Water Group coupon}

Recently, it was developed a new coupon sampling device for in situ studies, the Pennine Water Group (PWG). This coupon can be inserted directly into the pipes of DWDS, maintaining flow conditions representative these near wall pipe and enabling simultaneous quantitative and qualitative compositional characterization of in situ biofilms (Deines et al., 2010). This offers improvements over alternative sampling devices and the coupons are comprised of two parts, an "outer coupon" and an "insert" (Fig. 9). The outer coupon retains the curvature of the pipe and fits precisely into a hole made in a removable and flanged identical pipe section. The coupon is fixed with a gasket to a section pipe. The insert is engineered flat to allow microscopic analysis and it fits inside of the outer coupon in a way to allow the outer surface to be in direct contact with the water. This design has a maximum deviation from curvature of $0.064 \mathrm{~mm}$, in the order of magnitude of the surface roughness coefficient used in hydraulic models (Deines et al., 2010). It is an accurate device and allows direct insertion and close alignment with the internal pipe surface, minimizing the distortion of boundary layer conditions that influence biofilm formation, such as boundary shear stress

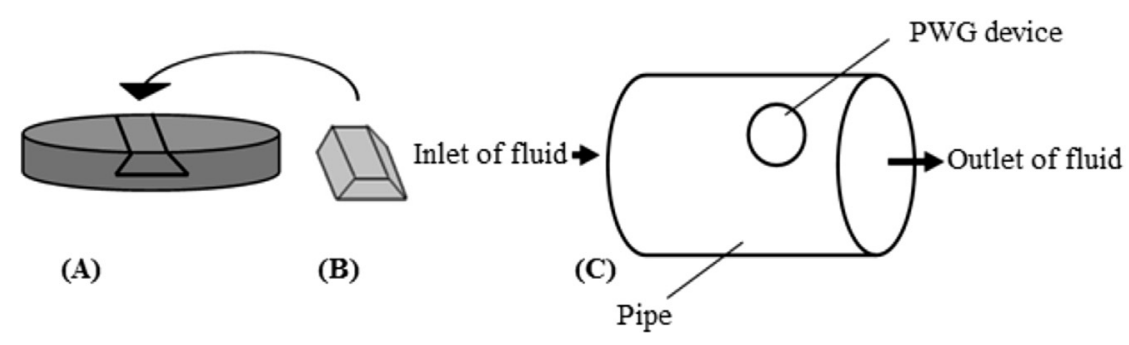

Fig. 9 - Pennine water group (PWG) coupon. (A) The outer coupon, where is located the insert; (B) insert; (C) pipe with the appropriate hole to locate the outer coupon with the insert fixed with a gasket. 
and turbulent driven exchange with the bulk water body (Douterelo et al., 2013). This coupon was used in a full-scale laboratory pipe loop. Deines et al. (2010) used a constant flow rate of $0.4 \mathrm{~L} \mathrm{~s}^{-1}$ (boundary shear stress of $0.03 \mathrm{~N} \mathrm{~m}^{-2}$ ) and it was observed an increase in bacterial biofilm coverage of the coupon surface over time, as well as, the development of increasingly complex biofilm communities. Douterelo et al. (2013) used PWG coupons to evaluate the effect of different and variable flow rates $\left(0.2-0.5 \mathrm{~L} \mathrm{~s}^{-1} ; 0.2-0.8 \mathrm{~L} \mathrm{~s}^{-1}\right.$ and $0.4 \mathrm{~L} \mathrm{~s}^{-1}$ ) on biofilm development and detachment from pipe walls. They concluded that different hydraulic regimes affect the composition and diversity of bacterial communities in biofilms. However, the use of increasing flow rates did not completely remove bacteria from pipe walls.

\subsection{Bioprobe monitor}

The bioprobe monitor was specifically designed to study biofilm growth within a pipe system. LeChevallier et al. (1998) described a pilot-scale DWDS $(1.3 \mathrm{~km})$ that had an experimental test station with $24 \mathrm{~m}$ and contained three test sections. A bioprobe monitor was located at the beginning of each experimental section to monitor the environmental conditions and biofilm development. The bioprobe monitor consists of a pipe where it is inserted a coupon holder (denominated acetal) being the coupon surface flushed with the pipe wall (Fig. 10). LeChevallier et al. (1998) also used this device to study the effects of chlorine and monochlorine on biofilm development at a water flow rate of $0.07 \mathrm{~L} \mathrm{~s}^{-1}$. These authors observed that the density of bacteria on the iron surfaces reached a maximum when the temperatures were higher and when there was a total declination of chlorine residuals. Also, they observed lower cell densities in the first section of the pilotscale DWDS and this was due to the fact that more chlorine reached this part of the system.

\subsection{Other in situ devices}

Other devices were used for in situ DW biofilm studies. Juhna et al. (2007) used a biofilm sampler that consists in a coupon holder inside of a pipe section. The authors used a total of 22 holders exposed to DW in a DWDS from Latvia and France to detect $E$. coli. This bacterium was found in $56 \%$ of the coupons using peptide nucleic acid fluorescent in situ hybridization (PNA-FISH), however, it was not detected using culture-based or enzymatic methods. The presence and amount of $E$. coli detected was not correlated with any physical and/or chemical characteristics of DW such as the temperature, chlorine or biodegradable organic matter (BOM) concentration. Helmi

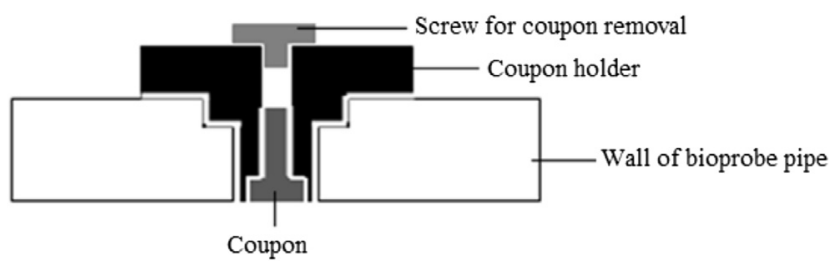

Fig. 10 - Scheme of the bioprobe monitor with a coupon insertion in the pipe. et al. (2010) used a pilot device constituted by 5 PVC compartments comprising a holder with six removable discs allowing the study of the effects of different surface materials on biofilm development. The device was connected to the tap of a DWDS operating at a flow rate of $2 \mathrm{~L} \mathrm{~min}^{-1}$ in order to study the interaction between virus and DW biofilms and to develop a method to detect viral particles in these biofilms. Five protocols were used for viral recovery, testing different sonication intensities ( $20 \%$ and $40 \%$ power intensity) and its combination with centrifugation (1500 g for $10 \mathrm{~min}$ ) and with $\mathrm{pH}$ neutralization. The most efficient protocol, that combined all the steps, allowed a recovery rate from $29.3 \%$ to $74.6 \%$ depending on the virus and on the material. The study of viral interactions with DW biofilms allowed to conclude that viral adsorption to biofilms depends on their isoelectric point, the disc material and the hydrodynamic conditions. For example, the viral adsorption to biofilms is less than $1 \%$ of the initial viral load when hydrodynamic conditions similar to those existing in DWDS were applied. Prévost et al. (1998) developed a study using a biofilm coupon device, known as the Prévost device. This device was installed on two DWDS of the city of Laval (Canada) and was used to remove the biofilm samples from the DWDS. The authors installed diverse devices in valve chambers and investigated the impact of nutrients levels and oxidant residual maintenance in the biofilms formed in the DWDS. They found that a low nutrient concentration reduced bacterial biomass. Nevertheless, the most significant differences were only observed in warm water and not in cold water.

Another device is the sliding coupon holder, a pilot-scale device (Chang et al., 2003). This device is a half PVC pipe where coupons are located, being easily removed and replaced after each experimental phase. Chang et al. (2003) used this device to determine the effects of blending different water qualities on the final quality of the water in the distribution system. The biofilm density was estimated on different pipe materials using a specific DNA-probe (BO-PRO 3). They concluded that this technique provided results that were correlated to these obtained from heterotrophic plate counts on R2A medium, after biofilm scrapping. Therefore, the technique used allowed to quantify fixed biomass without disrupting the biofilm.

Långmark et al. (2005) investigated the accumulation and fate of a model microbial pathogen in natural grown biofilms formed in a pilot-scale DWDS provided with chlorinated and UV-treated water. Two pilot-scale DWDS were used, comprising $1 \mathrm{~km}$ of polyethylene tubing that was connected directly to the finished water. The biofilm sample devices were chambers equipped with 20 exchangeable glass slides and were located at various distances along each DWDS pilot scale, corresponding to different residence times $(0.1,15,40$ and $110 \mathrm{~h}$ ) within the main Stockholm DWDS. It was not found a significant impact of primary disinfection processes on the accumulation and fate of pathogen models (L. pneumophila and bacteriophages) within the DWDS.

Other devices were constructed to study microfungal behavior in DWDS. Sammon et al. (2011) investigated the microfungi colonization of hard surfaces within the storage and distribution system by suspending artificial coupons within the water body of reservoirs. Sammon et al. (2011) 
used glass, PVC and concrete coupons held in sets of custommade racks. These racks were designed to held one coupon vertical and apart from the other coupons, to ensure a free flow of water across both surfaces of all coupons. The racks were placed in lidded plastic basket which was perforated on all sides, bottom and top. The basket was attached to nylon ropes and a clay house brick was used to held the basket at $1.5 \mathrm{~m}$ from the bottom. This work allowed to conclude that airborne spores introduced into reservoirs can be an important external source of microfungal propagules, however, it was also observed that the microfungi were not involved in the primary colonization of surfaces. The results also suggested that any aggregation of soft sediment in the DWDS was a potential site for the proliferation of the microfungal population. Siqueira et al. $(2011,2013)$ proposed the use of a distinct device to investigate natural filamentous fungi biofilms in DWDS, the sampler device. The core of the sampler device consists of hollow PVC pipes with polyethylene or acetate coupons held in place to allow biofilm growth. The end of each sampler forms a screw to connect multiple samplers or to close the device with a cap after coupon removal from the water network. These features facilitated insertion, handling and removal of each sampler device after collection and preventing contact with external environment during the transport process. Finally, the pipes could be filled with water in order to maintain moisture and preserve the integrity of the biofilms formed on the coupons. Siqueira et al. (2013) used this device in a DWDS at Recife (Brazil), concluding that this device is useful to study DW biofilms and that Calcofluor White (CW) staining is a rapid and efficient method to detect filamentous fungi, allowing its differentiation by morphology. This study also demonstrated that fungi are likely to play an important role in DWDS biofilms and final water quality.

\section{Table 2 - Main advantages and limitations of some of the presented devices.}

\begin{tabular}{|c|c|c|}
\hline Reactors & Advantages & Limitations \\
\hline Annular reactor & $\begin{array}{l}\text { Allows the study of different materials at the same time; } \\
\text { interesting to assess the role of hydrodynamic } \\
\text { conditions on biofilms; high surface area; easy sampling } \\
\text { process; shear stress control independent from the fluid } \\
\text { flow }\end{array}$ & $\begin{array}{l}\text { The coupons can change the flow patterns; non-ideal } \\
\text { mixing; non-uniform biofilm formation }\end{array}$ \\
\hline CCR & $\begin{array}{l}\text { Interesting to assess the role of hydrodynamic } \\
\text { conditions on biofilms; allows testing different shear } \\
\text { stress conditions at the same time; allows periodical } \\
\text { sampling }\end{array}$ & $\begin{array}{l}\text { Only one surface material can be tested per experiment; } \\
\text { lack of sufficient sampling surface area; difficult } \\
\text { sampling process }\end{array}$ \\
\hline Propella $^{(B)}$ & $\begin{array}{l}\text { Easy control of the flow conditions; residence time } \\
\text { controlled independently from the flowing process; flow } \\
\text { conditions very similar to DWDS; allows the } \\
\text { simultaneous study of different materials; allows } \\
\text { periodical sampling }\end{array}$ & $\begin{array}{l}\text { Changes in the flow caused by coupons; lack of sufficient } \\
\text { sampling surface area }\end{array}$ \\
\hline Flow cell reactor & $\begin{array}{l}\text { Flow conditions similar to DWDS; independent sampling } \\
\text { at the desired time without changing or stopping the } \\
\text { flow; allows the study of different materials at the same } \\
\text { time; easy to control environmental conditions }\end{array}$ & $\begin{array}{l}\text { Flow changed by the coupons; biofilms are formed on a } \\
\text { flat surface; lack of sufficient sampling surface area }\end{array}$ \\
\hline RDR & $\begin{array}{l}\text { Possibility to study different materials; easy to control of } \\
\text { operational conditions; allows testing different shear } \\
\text { stresses simultaneously }\end{array}$ & $\begin{array}{l}\text { The flow changes in the boundaries of the coupons; the } \\
\text { biofilm is formed on a flat surface; lack of sufficient } \\
\text { sampling surface area }\end{array}$ \\
\hline CDC biofilm reactor & $\begin{array}{l}\text { Allows the study of different materials simultaneously; } \\
\text { easy control of hydrodynamic conditions }\end{array}$ & $\begin{array}{l}\text { The surface where biofilms are formed is flat; difficult } \\
\text { control of the shear stress; changes of the flow pattern in } \\
\text { the boundaries of the coupons; lack of sufficient } \\
\text { sampling surface area }\end{array}$ \\
\hline Microtiter plates & $\begin{array}{l}\text { Needs small space; high-throughput analysis, easy to } \\
\text { control environmental conditions; non-invasive } \\
\text { analysis of cell adhesion and biofilm formation }\end{array}$ & $\begin{array}{l}\text { Low similarity to DWDS; batch system; unable to study } \\
\text { high shear stress conditions; volume limitations }\end{array}$ \\
\hline Robbins device & $\begin{array}{l}\text { Can be applied to real DWDS with operational conditions } \\
\text { very similar to reality; allows the study of different } \\
\text { materials simultaneously }\end{array}$ & $\begin{array}{l}\text { The flow characteristics are changed with the presence } \\
\text { of the coupons; the operational conditions cannot be } \\
\text { effectively controlled when used in real DWDS; lack of } \\
\text { sufficient sampling surface area }\end{array}$ \\
\hline MRD & $\begin{array}{l}\text { Can be applied to real DWDS with operational conditions } \\
\text { very similar to the reality; minimizes the changes in flow } \\
\text { in the boundaries of coupons; allows the study of } \\
\text { different materials simultaneously }\end{array}$ & $\begin{array}{l}\text { Limitations in the control of operational conditions; lack } \\
\text { of sufficient sampling surface area }\end{array}$ \\
\hline PWG coupon & $\begin{array}{l}\text { Useful to be used at pilot-scale DWDS; do not change the } \\
\text { flow conditions, curved structure as the DWDS pipes; } \\
\text { lack of sufficient sampling surface area; allows the study } \\
\text { of different materials }\end{array}$ & $\begin{array}{l}\text { Limitations in the control of operational conditions; lack } \\
\text { of sufficient sampling surface area }\end{array}$ \\
\hline Bioprobe monitor & $\begin{array}{l}\text { Allows to assess biofilm development in situ; changes in } \\
\text { water flow are minimized; allows the study of different } \\
\text { materials }\end{array}$ & $\begin{array}{l}\text { Limitation in the control of operational conditions; } \\
\text { limited available information; lack of sufficient sampling } \\
\text { surface area }\end{array}$ \\
\hline
\end{tabular}


Table 3 - Overview of DW biofilm studies the main operational conditions and microorganisms used.

\begin{tabular}{|c|c|c|c|c|c|c|c|}
\hline \multirow[t]{2}{*}{ Reactor } & \multicolumn{4}{|c|}{ Factors } & \multirow[t]{2}{*}{ Disinfectants } & \multirow[t]{2}{*}{ Microorganisms } & \multirow[t]{2}{*}{ References } \\
\hline & Material & Hydrodynamics & Temperature & Nutrients & & & \\
\hline Annular reactor & Mild steel & $\begin{array}{l}\text { Rotation speed: } \\
60 \mathrm{rpm}\end{array}$ & $10^{\circ} \mathrm{C}$ & - & Chlorine $\left(1.3 \mathrm{mg} \mathrm{L}^{-1}\right)$ & $\begin{array}{l}\text { Tap water } \\
\text { microorganisms }\end{array}$ & Volk and LeChevallier (1999) \\
\hline Annular reactor & Polycarbonate & $\begin{array}{l}\text { Residence time: } \\
4.3 \mathrm{~h} \text {; Flow rate: } \\
3 \mathrm{~mL} \mathrm{~min}^{-1}\end{array}$ & $25^{\circ} \mathrm{C}$ & $\begin{array}{l}\text { Potassium, phosphate } \\
\text { and sodium acetate }\end{array}$ & $\begin{array}{l}\text { Chloramine }(0.70 \\
\left.-1.4 \mathrm{mg} \mathrm{L}^{-1}\right)\end{array}$ & $\begin{array}{l}\text { Tap water } \\
\text { microorganisms }\end{array}$ & Chandy and Angles (2001) \\
\hline Annular reactor & Polycarbonate & $\begin{array}{l}\text { Rotation speed: } \\
40 \mathrm{rpm}\end{array}$ & - & $\begin{array}{l}\text { Carbon stock solution } \\
\left(0.235 \mathrm{mg} \mathrm{L}^{-1}\right) \text {; } \\
\text { phosphate addition } \\
\left(0.5 \mathrm{mg} \mathrm{P} \mathrm{L}^{-1}\right)\end{array}$ & $\begin{array}{l}\text { Chlorine and } \\
\text { monochlorine }(0.6 \\
\left.-0.9 \mathrm{mg} \mathrm{L}^{-1}\right)\end{array}$ & $\begin{array}{l}\text { Tap water } \\
\text { microorganisms }\end{array}$ & Batté et al. (2003b) \\
\hline Annular reactor & PVC & $\begin{array}{l}\text { Shear stress: } \\
0.25 \mathrm{~N} \mathrm{~m}^{-2}\end{array}$ & 6,12 and $22{ }^{\circ} \mathrm{C}$ & $\begin{array}{l}\text { Sodium acetate, sodium } \\
\text { nitrate and potassium } \\
\text { di-hydrogen phosphate }\end{array}$ & $\begin{array}{l}\text { Chloramine (0.2 } \\
-0.6 \mathrm{mg} \mathrm{L}^{-1} \text { and } 0.05 \\
\left.-0.1 \mathrm{mg} \mathrm{L}^{-1}\right) \text {, chlorine } \\
\text { (residual concentration) }\end{array}$ & $\begin{array}{l}\text { Ammonia-oxidizing } \\
\text { bacteria }\end{array}$ & Pintar and Slawson (2003) \\
\hline Annular reactor & $\begin{array}{l}\text { Cast iron and } \\
\text { polycarbonate }\end{array}$ & $\begin{array}{l}\text { Shear stress: } \\
0.25 \mathrm{~N} \mathrm{~m}^{-2}\end{array}$ & $20^{\circ} \mathrm{C}$ & - & $\begin{array}{l}\text { Chlorite }(0.1 \text { and } \\
\left.0.25 \mathrm{mg} \mathrm{L}^{-1}\right) \text { and } \\
\text { chlorine dioxide }(0.25 \\
\left.\text { and } 0.5 \mathrm{mg} \mathrm{L}^{-1}\right)\end{array}$ & $\begin{array}{l}\text { Tap water } \\
\text { microorganisms }\end{array}$ & Gagnon et al. (2004) \\
\hline Annular reactor & $\begin{array}{l}\text { Cast iron and } \\
\text { polycarbonate }\end{array}$ & $\begin{array}{l}\text { Shear stress: } \\
0.25 \mathrm{~N} \mathrm{~m}^{-2}\end{array}$ & $20^{\circ} \mathrm{C}$ & $\begin{array}{l}\text { Nitrate, phosphate and } \\
\text { biodegradable organic } \\
\text { carbon }\end{array}$ & $\begin{array}{l}\text { Free chlorine (0.5 } \\
\left.-1.0 \mathrm{mg} \mathrm{L}^{-1}\right) \text {, chlorine } \\
\text { dioxide }(0.25 \\
\left.-0.5 \mathrm{mg} \mathrm{L}^{-1}\right) \text { and } \\
\text { chloramines }(1 \\
\left.-2 \mathrm{mg} \mathrm{L}^{-1}\right)\end{array}$ & $\begin{array}{l}\text { Tap water } \\
\text { microorganisms }\end{array}$ & Gagnon et al. (2005) \\
\hline Annular reactor & PVC & $\begin{array}{l}\text { Rotation speed: } \\
92 \mathrm{rpm}\end{array}$ & 6,12 and $18{ }^{\circ} \mathrm{C}$ & $\begin{array}{l}\text { Carbon }(0 \text { and } \\
\left.250 \mu \mathrm{g} \mathrm{C} \mathrm{L}^{-1}\right)\end{array}$ & $\begin{array}{l}\text { Chlorine }(0.05 \\
\left.-0.23 \mathrm{mg} \mathrm{L}^{-1}\right)\end{array}$ & $\begin{array}{l}\text { Tap water } \\
\text { microorganisms }\end{array}$ & Ndiongue et al. (2005) \\
\hline Annular reactor & $\begin{array}{l}\text { SS and medium- } \\
\text { density polyethylene } \\
\text { (MDPE) }\end{array}$ & $\begin{array}{l}\text { Rotation speed: } \\
150 \mathrm{rpm}\end{array}$ & $15^{\circ} \mathrm{C}$ & - & - & $\begin{array}{l}\text { Aquabacterium } \\
\text { commune }\end{array}$ & Bachmann and Edyvean (2006) \\
\hline Annular reactor & Polycarbonate & $\begin{array}{l}\text { Shear stress: } \\
0.25 \mathrm{~N} \mathrm{~m}^{-2}\end{array}$ & $20^{\circ} \mathrm{C}$ & $\begin{array}{l}\text { Ethyl alcohol, } \\
\text { propionaldehyde, } \\
\text { oxalate, pyruvate, and } \\
\text { acetate }\end{array}$ & $\begin{array}{l}\text { UV radiation } \\
\left(45 \mathrm{~mJ} \mathrm{~cm}^{-2}\right) \text {, free } \\
\text { chlorine }(0.5 \text { and } \\
\left.1.0 \mathrm{mg} \mathrm{L}^{-1}\right) \text {, chlorine } \\
\text { dioxide }(0.25 \text { and } \\
\left.0.5 \mathrm{mg} \mathrm{L}^{-1}\right) \text { and } \\
\text { monochloramine }(1.0 \\
\left.\text { and } 2.0 \mathrm{mg} \mathrm{L}^{-1}\right)\end{array}$ & $\begin{array}{l}\text { Tap water } \\
\text { microorganisms }\end{array}$ & Dykstra et al. (2007) \\
\hline Annular reactor & Polycarbonate & $\begin{array}{l}\text { Shear stress: } \\
0.68 \mathrm{~N} \mathrm{~m}^{-2}\end{array}$ & $24^{\circ} \mathrm{C}$ & - & $\begin{array}{l}\text { UV radiation, chlorine } \\
\left(0.20 \mathrm{mg} \mathrm{L}^{-1}\right) \text { and } \\
\text { chlorine dioxide }\end{array}$ & $\begin{array}{l}\text { Tap water } \\
\text { microorganisms }\end{array}$ & Rand et al. (2007) \\
\hline Annular reactor & Polycarbonate & $\begin{array}{l}\text { Rotation speed: } \\
100 \mathrm{rpm}\end{array}$ & $21-23^{\circ} \mathrm{C}$ & - & $\begin{array}{l}\text { Chlorine }(0.6 \\
\left.-1.0 \mathrm{mg} \mathrm{L}^{-1}\right)\end{array}$ & Klebsiella pneumoniae & Szabo et al. (2006) \\
\hline Annular reactor & Teflon & - & - & $\begin{array}{l}1-3 \mathrm{mg} \mathrm{L}^{-1} \text { organic } \\
\text { carbon }\end{array}$ & - & $\begin{array}{l}\text { Tap water } \\
\text { microorganisms }\end{array}$ & Schaule et al. (2007) \\
\hline
\end{tabular}




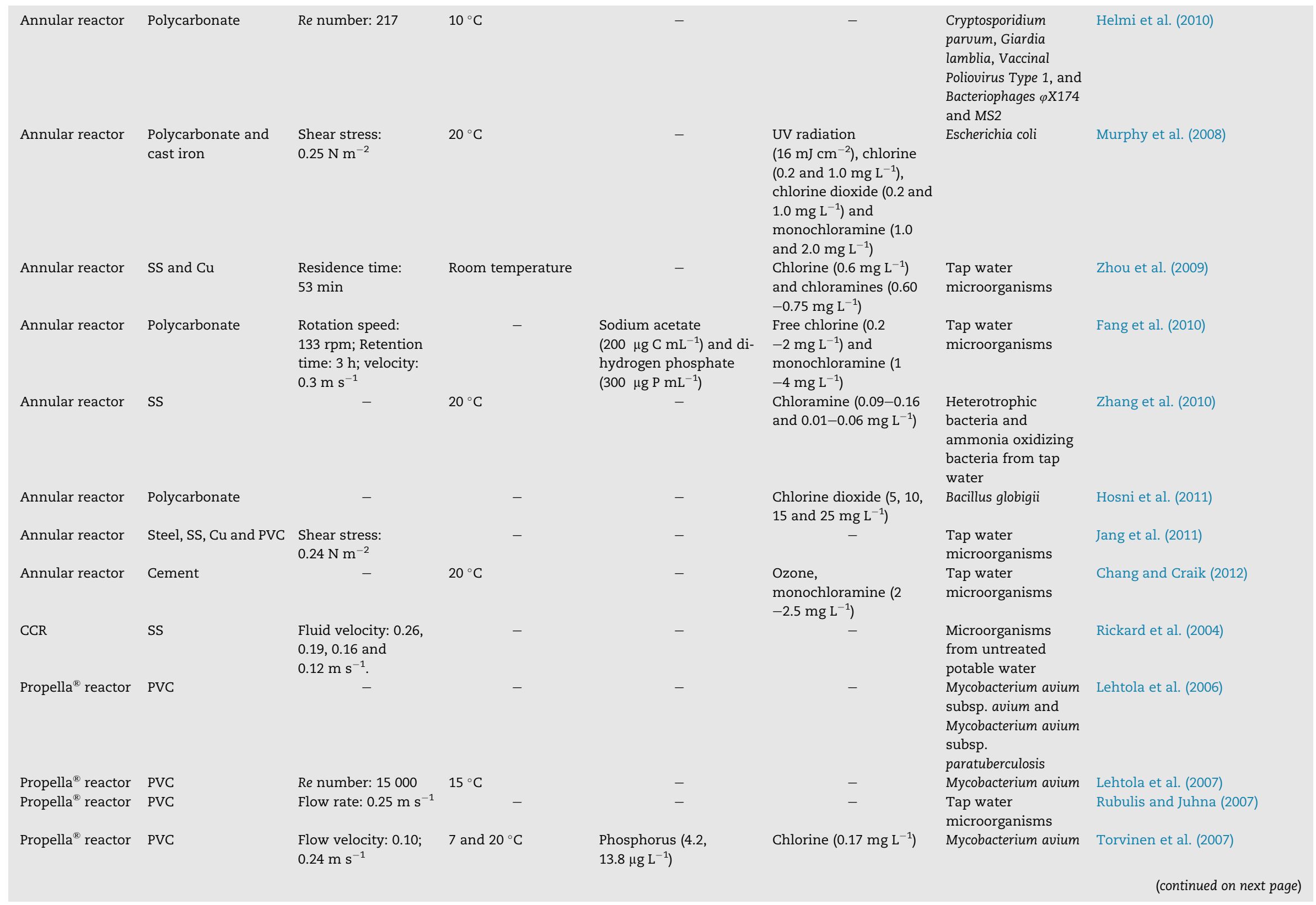




\begin{tabular}{|c|c|c|c|c|c|c|c|}
\hline \multirow[t]{2}{*}{ Reactor } & \multicolumn{4}{|c|}{ Factors } & \multirow[t]{2}{*}{ Disinfectants } & \multirow[t]{2}{*}{ Microorganisms } & \multirow[t]{2}{*}{ References } \\
\hline & Material & Hydrodynamics & Temperature & Nutrients & & & \\
\hline Propella ${ }^{\circledR}$ Reactor & PVC and SS 316 & $\begin{array}{l}\text { Water velocity: } \\
0.13 \mathrm{~m} \mathrm{~s}^{-1} \text {; retention } \\
\text { time: } 12 \mathrm{~h}\end{array}$ & $20^{\circ} \mathrm{C}$ & - & $\begin{array}{l}\text { Fenton reaction (iron } \\
\text { particles at } 10^{-1} ; 10^{-2} ; \\
5 \times 10^{-2} \text { and } 10^{-3} \mathrm{M} \mathrm{Fe} \text {, } \\
\text { hydrogen peroxide at } \\
1.5 \times 10^{-2} \mathrm{M} \text { ) }\end{array}$ & $\begin{array}{l}\text { Tap water } \\
\text { microorganisms }\end{array}$ & Gosselin et al. (2013) \\
\hline Flow cell system & PVC and SS & $\begin{array}{l}\text { Re number: } 2000 \text { and } \\
11000\end{array}$ & $20^{\circ} \mathrm{C}$ & $\begin{array}{l}\text { Carbon }\left(0.5 \mathrm{mg} \mathrm{L}^{-1}\right) \text {, } \\
\text { nitrogen }\left(0.1 \mathrm{mg} \mathrm{L}^{-1}\right) \text { and } \\
\text { phosphorus } \\
\left(0.01 \mathrm{mg} \mathrm{L}^{-1}\right)\end{array}$ & - & $\begin{array}{l}\text { Tap water } \\
\text { microorganisms }\end{array}$ & Simões et al. (2006) \\
\hline Flow cell system & PVC & $\begin{array}{l}\text { Re number: } 4900 \text { and } \\
810\end{array}$ & $20^{\circ} \mathrm{C}$ & - & - & $\begin{array}{l}\text { Tap water } \\
\text { microorganisms }\end{array}$ & Manuel et al. (2010) \\
\hline $\begin{array}{l}\text { Flow cell reactor } \\
\text { and Propella }{ }^{\circledR} \\
\text { reactor }\end{array}$ & $\begin{array}{l}\text { PVC, cross linked } \\
\text { polyethylene (PEX), } \\
\text { HDPE and PP } \\
\text { (polypropylene) }\end{array}$ & $\begin{array}{l}\text { Shear stress: } 0.80 \\
\text { and } 1.91 \mathrm{~Pa}\end{array}$ & $15.9^{\circ} \mathrm{C}$ & - & - & $\begin{array}{l}\text { Tap water } \\
\text { microorganisms }\end{array}$ & Manuel et al. (2007) \\
\hline $\begin{array}{l}\text { Flow cell system } \\
\text { and Propella }{ }^{\circledR} \\
\text { reactor }\end{array}$ & PVC and SS 316 & $\begin{array}{l}\text { Re number: } 2000 \text { and } \\
11000\end{array}$ & $20^{\circ} \mathrm{C}$ & - & - & $\begin{array}{l}\text { Tap water } \\
\text { microorganisms }\end{array}$ & Simões et al. (2012) \\
\hline RDR & SS & - & $30^{\circ} \mathrm{C}$ & $\begin{array}{l}\text { Yeast extract, proteose } \\
\text { peptone, casamino } \\
\text { acids, dextrose }\left(0.5 \mathrm{~g} \mathrm{~L}^{-1}\right) \\
\text { sodium pyruvate and } \\
\text { dibasic potassium } \\
\text { phosphate }\left(0.03 \mathrm{~g} \mathrm{~L}^{-1}\right) \text {, } \\
\text { magnesium phosphate } \\
\left(0.005 \mathrm{~g} \mathrm{~L}^{-1}\right)\end{array}$ & - & $\begin{array}{l}\text { Legionella } \\
\text { pneumophila and } \\
\text { Hartmannella } \\
\text { vermiformis }\end{array}$ & Murga et al. (2001) \\
\hline $\mathrm{RDR}$ & Glass & Shear stress: $0.12 \mathrm{~Pa}$ & $21^{\circ} \mathrm{C}$ & - & - & $\begin{array}{l}\text { Tap water } \\
\text { microorganisms }\end{array}$ & Abe et al. (2011) \\
\hline RDR & HDPE & $\begin{array}{l}\text { Shear rate: } 450 \\
-1640 \mathrm{~s}^{-1}\end{array}$ & $20^{\circ} \mathrm{C}$ & - & - & $\begin{array}{l}\text { MS2, GA and Q } \beta \\
\text { phages replicated } \\
\text { using E. coli }\end{array}$ & Pelleïeux et al. (2012) \\
\hline $\begin{array}{l}\text { CDC reactor and } \\
\text { Pipe loop } \\
\text { reactor }\end{array}$ & $\mathrm{PVC}$ and $\mathrm{Cu}$ & $\begin{array}{l}\text { Flow rate: } \\
1 \mathrm{~mL} \mathrm{~min}{ }^{-1} \text { (pipe } \\
\text { loop reactor); } \\
0.3 \mathrm{~mL} \mathrm{~min}^{-1}\end{array}$ & - & Humic acids & $\begin{array}{l}\text { Free chlorine (10 and } \\
\left.103 \mathrm{mg} \mathrm{L}^{-1}\right) \text {, } \\
\text { monochloramine }(13,49 \\
\left.\text { and } 99 \mathrm{mg} \mathrm{L}^{-1}\right)\end{array}$ & Bacillus spores & Morrow et al. (2008) \\
\hline CDC reactor & PVC & $\begin{array}{l}\text { Rotation speed: } \\
50 \mathrm{rpm}\end{array}$ & $25-29^{\circ} \mathrm{C}$ & - & - & $\begin{array}{l}\text { Tap water } \\
\text { microorganisms }\end{array}$ & Park and Hu (2010) \\
\hline CDC reactor & PVC and SS & - & - & - & $\begin{array}{l}\text { Monochloramine (1 or } \\
2 \mathrm{mg} \mathrm{L}^{-1} \text { ) }\end{array}$ & $\begin{array}{l}\text { Sphingomonas } \\
\text { paucimobilis, } \\
\text { Methylobacterium sp., } \\
\text { Delftia acidovorans, } \\
\text { and Mycobacterium } \\
\text { mucogenicum }\end{array}$ & Armbruster et al. (2012) \\
\hline
\end{tabular}




\begin{tabular}{|c|c|c|c|c|c|c|c|}
\hline $\mathrm{CDC}$ reactor & PVC & $\begin{array}{l}\text { Shear stress: } \\
0.01 \mathrm{~N} \mathrm{~m}^{-2}\end{array}$ & $25-29^{\circ} \mathrm{C}$ & - & - & $\begin{array}{l}\text { Tap water } \\
\text { microorganisms }\end{array}$ & Park et al. (2012) \\
\hline Microtiter plates & Polystyrene & - & $23^{\circ} \mathrm{C}$ & - & - & $\begin{array}{l}\text { Acinetobacter } \\
\text { calcoaceticus, } \\
\text { Burkholderia cepacia, } \\
\text { Methylobacterium sp., } \\
\text { Mycobacterium } \\
\text { mucogenicum, } \\
\text { Sphingomonas } \\
\text { capsulata and } \\
\text { Staphylococcus sp. } \\
\text { (DW isolated- } \\
\text { bacteria) }\end{array}$ & Simões et al. (2010a) \\
\hline Microtiter plates & Polystyrene & - & $23^{\circ} \mathrm{C}$ & 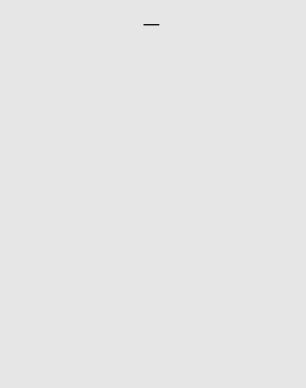 & $\begin{array}{l}\text { Sodium hypochlorite } \\
\left(0.1,0.5 ; 1 \text { and } 10 \mathrm{mg} \mathrm{L}^{-1}\right)\end{array}$ & $\begin{array}{l}\text { Acinetobacter } \\
\text { calcoaceticus, } \\
\text { Burkholderia cepacia, } \\
\text { Methylobacterium sp., } \\
\text { Mycobacterium } \\
\text { mucogenicum, } \\
\text { Sphingomonas } \\
\text { capsulata and } \\
\text { Staphylococcus sp. } \\
\text { (DW isolated- } \\
\text { bacteria) }\end{array}$ & Simões et al. (2010b) \\
\hline $\begin{array}{l}\text { Glass ring } \\
\text { column }\end{array}$ & Glass & $\begin{array}{l}\text { Hydraulic retention } \\
\text { time: } 0.5 \mathrm{~d}\end{array}$ & $25^{\circ} \mathrm{C}$ & Acetate $\left(0.5 \mathrm{mg} \mathrm{L}^{-1}\right)$ & Chlorine $\left(3.0 \mathrm{mg} \mathrm{L}^{-1}\right)$ & $\begin{array}{l}\text { Tap water } \\
\text { microorganisms, } \\
\text { namely Pseudomonas } \\
\text { fluorescens and } \\
\text { Spirillum species }\end{array}$ & Ginige et al. (2011) \\
\hline Robbins device & Polyethylene & $\begin{array}{l}\text { Water velocity: } \\
0.5 \mathrm{~m} \mathrm{~s}^{-1}\end{array}$ & - & - & $\begin{array}{l}\text { Chlorine }(0.08 \\
\left.-0.73 \mathrm{mg} \mathrm{L}^{-1}\right) \text {, chlorine } \\
\text { dioxide }(<0.01 \\
\left.-0.27 \mathrm{mg} \mathrm{L}^{-1}\right)\end{array}$ & $\begin{array}{l}\text { Tap water } \\
\text { microorganisms }\end{array}$ & Sly et al. (1990) \\
\hline MRD & $\begin{array}{l}\text { Glass and } \\
\text { Polyethylene }\end{array}$ & Flow rate: $0.6 \mathrm{~L} \mathrm{~h}^{-1}$ & $12.2^{\circ} \mathrm{C}$ & - & - & $\begin{array}{l}\text { Tap water } \\
\text { microorganisms }\end{array}$ & Kalmbach et al. (1997) \\
\hline MRD & PVC and SS & - & $24^{\circ} \mathrm{C}$ & Humic acid $\left(0.5 \mathrm{mg} \mathrm{L}^{-1)}\right.$ & Silver nitrate $\left(0.1 \mathrm{mg} \mathrm{L}^{-1}\right)$ & $\begin{array}{l}\text { Tap water } \\
\text { microorganisms }\end{array}$ & Silvestry-Rodriguez et al. (2008) \\
\hline PWG coupon & $\begin{array}{l}\text { High-performance } \\
\text { polyethylene (HPPE) }\end{array}$ & $\begin{array}{l}\text { Shear stress: } \\
0.03 \mathrm{~N} \mathrm{~m}^{-2}\end{array}$ & $25^{\circ} \mathrm{C}$ & - & - & $\begin{array}{l}\text { Tap water } \\
\text { microorganisms }\end{array}$ & Deines et al. (2010) \\
\hline PWG coupon & HDPE & $\begin{array}{l}\text { Growth conditions } \\
\left(0.2-0.5 \mathrm{~L} \mathrm{~s}^{-1} \text {, }\right. \\
0.4 \mathrm{~L} \mathrm{~s}^{-1} \text { and } 0.2 \\
\left.-0.8 \mathrm{~L} \mathrm{~s}^{-1}\right) \text {; flushing } \\
\text { conditions }(0.2 \\
\left.-3 \mathrm{~N} \mathrm{~m}^{2}\right)\end{array}$ & $16^{\circ} \mathrm{C}$ & - & Chlorine $\left(0.8 \mathrm{mg} \mathrm{L}^{-1}\right)$ & $\begin{array}{l}\text { Tap water } \\
\text { microorganisms }\end{array}$ & Douterelo et al. (2013) \\
\hline $\begin{array}{l}\text { Packed beads } \\
\text { column }\end{array}$ & Glass, SS and Teflon & $\begin{array}{l}\text { Water flow: } \\
1 \mathrm{~L} \mathrm{~min}^{-1}\end{array}$ & $16.0,19.4$ and $20.6^{\circ} \mathrm{C}$ & & Chlorine $\left(0.5 \mathrm{mg} \mathrm{L}^{-1}\right)$ & $\begin{array}{l}\text { Tap water } \\
\text { microorganisms }\end{array}$ & Delahaye et al. (2006) \\
\hline
\end{tabular}


The main advantages and limitations of the main devices described previously are synthesized in Table 2 . These are mostly related with the ability to study and control the hydrodynamic conditions, with the sampling process, the temperature control, the possibility to use different surface material, and the possibility to operate under conditions similar to the real systems.

\section{Main applications of reactors in DW biofilms studies}

In general, the main applications of several described reactors in studies of DW biofilms are monitoring the biofilm formation with different operational conditions (support material, hydrodynamics, temperature, nutrients, type of microorganisms, disinfectants) and biofilm control by different strategies (process conditions and disinfection). Table 3 synthesizes some of the studies on DW biofilms using reactors, making reference to the main process conditions and microorganisms used.

\subsection{Biofilm control}

Several strategies can be used to attempt biofilm prevention and control in DWDS. The pre-treatment of water, before being released into the DWDS is an important preventive measure and usually consists in the minimization of the organic matter and nutrients concentration entering the distribution system. The material selection to apply in the DWDS pipes and fittings is also important to control biofilm development. The use of antimicrobial compounds is common, being important to maintain a residual concentration of disinfectant inside the DWDS. Simões and Simões (2013) described usual and new techniques used to prevent and control biofilm formation in DW. Nonetheless, biofilm control by manipulating the operation conditions (temperature, flow rate and shear stress, presence of nutrients, material selection) is also a matter of study (Ndiongue et al., 2005; Rickard et al., 2004; Simões et al., 2006; Torvinen et al., 2007).

\subsubsection{Management of operational conditions}

To control biofilm development it is important to understand how its development happens and the role played by the operational conditions (Douterelo et al., 2013; Lehtola et al., 2007; Pintar and Slawson, 2003; Simões et al., 2006; Torvinen et al., 2007; Volk and LeChevallier, 1999). Ollos et al. (2003) evaluated the influence of several factors (BOM concentration, monochloramine and chlorine disinfection, flow velocity, pipe material and temperature) on biofilm development using as DWDS model an annular reactor. Under the conditions studied, the disinfectant residual was the most important factor for biofilm accumulation. In the absence of BOM, temperature seemed to have no effect, whereas shear stress seemed to be important. In the presence of BOM, temperature was important at low shear stress, although shear stress conditions themselves had little effect. The condition leading to the strongest biofilm accumulation was a high level of BOM combined with the absence of a disinfectant. The temperature effect was studied by Ndiongue et al. (2005) and Pintar and Slawson (2003) using an annular reactor, as previously referred. Torvinen et al. (2007), as already said, used a Propella ${ }^{\circledR}$ reactor to assess the effects of different temperatures on biofilm growth, but also studied the influence of flow velocity and phosphorous concentration.

The effect of hydrodynamic conditions was investigated in biofilm growth using diverse reactors. The flow cell system is one of the systems used to achieve this goal (Manuel et al., 2010; Simões et al., 2006), as well as the Propella ${ }^{\circledR}$ reactor (Lehtola et al., 2007). CCR and RDR allowed the evaluation of the effect of different shear stresses on biofilm development (Abe et al., 2012; Rickard et al., 2004). The in situ devices also can be used to study the hydrodynamic effects on biofilm development, simulating a flushing situation, as did by Douterelo et al. (2013) using the PWG coupon, as previously referred.

Another important aspect that can help to control biofilm development is the type of surface material. The annular reactor was expressively used with this aim. Camper et al. (2003) used the annular reactor with ductile-iron, PVC, epoxy, and cement-lined coupons to assess the interactions between pipe materials, organic carbon levels, and disinfectants. The study was carried out in the laboratory and at four field sites. The laboratorial study used biologically treated water with and without $0.2 \mathrm{mg} \mathrm{L}^{-1}$ residual free chlorine or monochloramine, in the presence or absence of 0.5 or $2.0 \mathrm{mg} \mathrm{L}^{-1}$ humic substances. These authors concluded that in the lab study regardless the carbon level, PVC systems were typically colonized with the lowest numbers of bacteria, whereas iron had the highest. Cement and epoxy systems had intermediate numbers. On the other hand, depending on the site, field studies showed that iron had the highest numbers of attached bacteria. In other cases, no differences were encountered on surface colonization due to the type of material. Zhou et al. (2009) also used this device to study the effects of surface material (SS and copper - $\mathrm{Cu}$ ) on disinfection by chlorine and chloramines. The results showed that biofilm formation was affected either by the type of disinfectant as well as by the type of pipe material. Chloramines were more effective than chlorine in controlling biofilms formed on both SS and $\mathrm{Cu}$ surfaces. The tested pipe materials did affect bacterial accumulation when chlorine and chloramines were present. There were fewer bacteria attached to $\mathrm{Cu}$ slides with chloramines or chlorine disinfection when compared with SS. The combination of $\mathrm{Cu}$ pipes and chloramines as the disinfectant was the most efficient combination to get low biofilm accumulation. Jang et al. (2011) did a similar study comparing the influence of steel, SS, Cu and PVC on biofilm formation and water quality. An annular reactor with coupons of these materials was operated under hydraulic conditions similar to a real plumbing system (50 rpm, $0.25 \mathrm{~N} \mathrm{~m}^{-2}$, approx. $0.3 \mathrm{~ms}^{-1}$ ), at a flow rate of $170 \mathrm{~mL} \mathrm{~min}^{-1}$ for 15 months. The results showed that biofilm formation and water quality were substantially affected by the pipe materials. The bacterial concentration and species diversity in the biofilms increased with the corrosion of the pipe. The bacterial accumulation was 100 times higher on steel pipe than on the other pipe materials. SS demonstrated to be the best material among those tested, with the lower levels of attached cells.

The control of nutrients in water can be used to mitigate biofilm formation. In order to ascertain the influence of this 
parameter in biofilm formation, some authors used pretreatment strategies to remove the nutrients of real tap water, while others used synthetic water with different nutrient concentrations. Reverse osmoses (RO) is one of the methods used and can improve the water quality by reducing organic, inorganic and bacterial contents (Simões and Simões, 2013). Park and Hu (2010) compared biofilm growth in a CDC reactor fed with real tap water and fed with tap water previously treated through RO. The Propella ${ }^{\circledR}$ reactor was used to prevent biofilm formation by controlling phosphorus concentration (Rubulis and Juhna, 2007). The annular reactor was also used to study the influence of nutrients in biofilm growth. Chandy and Angles (2001) and Fang et al. (2010) used this device to determine the impact of nutrient limitation on biofilm growth and disinfectant decay. The first study found that biofilm development was limited by organic carbon and that biofilm development promoted chloramine decay. The removal of nutrients resulted in stable chlorine persistence, which led to higher biofilm control. The authors proposed that the treatment and operational management strategies should incorporate organic carbon removal to limit biofilm development through a combination of retarding bacterial growth and enhancing disinfectant persistence. Fang et al. (2010) developed DW biofilms in this device to examine the effects of phosphorus on disinfection with free chlorine and monochloramine. The disinfection efficacy was increased by phosphorus addition. The presence of phosphorus was found to increase the biofilm cell numbers but decreased EPS production. At the same disinfection dosages, monochloramine showed greater biofilm removal efficiency than free chlorine. These authors proposed that monochloramine could be a better choice than free chlorine in DW biofilm disinfection, when phosphorus is added as the corrosion inhibitor.

\subsubsection{Disinfection strategies}

Even if chlorine is the chemical agent most widely used for DW disinfection, studies are still performed to optimize disinfection strategies and to find alternative solutions. The annular reactor was used in several studies to evaluate different control strategies and the frequently tested disinfectants were those chlorine-based, as free chlorine, monochloramine and chlorine dioxide (Batté et al., 2003b; Chang and Craik, 2012; Dykstra et al., 2007; Gagnon et al., 2004; Murphy et al., 2008; Pintar and Slawson, 2003; Rand et al., 2007). However, other strategies were tested, including ozone (Chang and Craik, 2012), the combination of UV treatment with free chlorine, monochloramine and chlorine dioxide (Dykstra et al., 2007; Murphy et al., 2008; Rand et al., 2007). Fenton reaction was tested in a Propella ${ }^{\circledR}$ reactor by Gosselin et al. (2013). Morrow et al. (2008) and Hosni et al. (2011) used a CDC reactor to developed disinfection strategies also based in chlorine derivative disinfectants and UV treatment. Armbruster et al. (2012) considered that the comprehension of the extent of interaction between opportunistic pathogens with biofilms is needed to understand their role in DWDS. These authors used a CDC reactor to develop a multispecies biofilm and tested the disinfection efficiency of monochloramine. Silvestry-Rodriguez et al. (2008) studied the effect of silver on biofilm disinfection using an MRD, as previously referred.

\subsection{Biofilm monitoring}

Another strategy to understand biofilm formation and behavior is by their monitoring. The best devices for biofilm monitoring are those that have removable coupons, allowing the assessment of the gradual biofilm development and the changes during all formation stages. The use of appropriate coupons is also an important issue because the monitoring of the heterogenous distribution of the biofilm over the surface area of the reactors is difficult due to the size and the shape of the surface (Okabe et al., 1995).

Simões et al. (2006) used a flow cell system to monitor biofilm development under different operational conditions (shear stress, support material and nutrients). Torvinen et al. (2007) used the Propella ${ }^{\circledR}$ reactor to follow the influence of flow velocity, phosphorus concentration and temperature on the survival of $M$. avium in biofilms. A similar application of Propella ${ }^{\circledR}$ reactor was done by Lehtola et al. (2006). Manuel et al. (2007) used both previously described reactors to monitor and evaluate how the dynamic conditions affected the stability of biofilms.

The RDR was used to monitor L. pneumophila survival on biofilms during 15 days (Murga et al., 2001). Pelleïeux et al. (2012) used a similar device to monitor the accumulation of enteric viruses on surfaces within a DWDS.

The annular reactor is often used to monitor DW biofilm development (Bachmann and Edyvean, 2006; Schaule et al., 2007; Zhang et al., 2010). Zhang et al. (2010) monitored the presence of heterotrophic and ammonia oxidizing bacteria (AOB) in biofilms to determine the potential relationship between the abundance of heterotrophic bacteria and of $A O B$, using an annular reactor. Bachmann and Edyvean (2006) used this device to study biofilm development of Aquabacterium commune on SS. Schaule et al. (2007) used an annular reactor linked to three sensors to gather information on the biofilm cell density. Even if this device allows online monitoring, the existence of coupons is essential for microbiological characterization. van der Kooij et al. (1995) used a glass column device to monitor the effects of support material, water type and nutrients on the rate and extent of biomass accumulation.

The use of biofilm-forming devices as a by-pass or directly connected to a DWDS has been a commonly used strategy to allow a more efficient monitoring of biofilm formation in pilot and real systems (Hallam et al., 2001). Sly et al. (1990) used the Robbins device to monitor the deposition of manganese in the presence of biofilms. Silvestry-Rodriguez et al. (2008) used the same device to monitor the effects of silver in biofilm control using tap water in an experimental plant.

Deines et al. (2010) and Douterelo et al. (2013) used the PWG device to study the diversity of biofilm communities within DWDS, as previously referred.

\section{Quantification of biofilms in DWDS models}

All the biofilm studies require the definition of an appropriate method to quantify biofilm formation and to provide information on its characteristics, particularly for the resident 
population. Biofilms can be quantified through the increase of biological activity or by the number of cells (Liu et al., 2013). Apart from the quantification of cell numbers, it is also important to obtain information on other biofilm constituents, particularly the EPS. Most of these methods require the biofilm scraping from the substratum and its dispersion in an adequate solution, generally saline water (Fang et al., 2009, 2010; Manuel et al., 2007; Park et al., 2012; SilvestryRodriguez et al., 2008; Zhou et al., 2009) or an appropriate buffer (Chang and Craik, 2012; Jang et al., 2012). Moreover, to achieve an efficient biofilm dispersion in the selected solution it is necessary to use some physical treatment as vortex and/ or ultrasonication (Chang and Craik, 2012; Fang et al., 2009, 2010; Jang et al., 2012; Manuel et al., 2007; Park et al., 2012; Silvestry-Rodriguez et al., 2008; Zhou et al., 2009). The exceptions to the scraping requirement are some microscopic methods, as atomic force microscopy (AFM), scanning electron microscopy and confocal scanning laser microscopy (CSLM), which can allow a direct analysis of biofilm adhered to a surface, if the sampling coupons are flat (Abe et al., 2012; Fang et al., 2010; Jungfer et al., 2013; Ling and Liu, 2013; Mathieu et al., 2014). However, even if the direct microscopic analysis of coupon surfaces is important to provide information on the biofilm structure, these methods cannot determine all relevant aspects involving the biofilm formation process. Therefore, the combination of information from different methods will provide a more detailed picture on DW biofilm formation and composition.

\subsection{Cell enumeration}

The biofilm quantification through cell enumeration is the mostly used method. The biofilm development and dynamics is commonly monitored through the enumeration of cultivable, metabolic active, viable and/or total cells (Chang and Craik, 2012; Fang et al., 2009, 2010; Gagnon et al., 2005; Jang et al., 2012; Jungfer et al., 2013; Manuel et al., 2007; Park et al., 2012; Silvestry-Rodriguez et al., 2008).

Heterotrophic plate count (HPC) methods are often used to assed the numbers of cultivable bacteria, usually described in terms of colony forming units (CFU) per unit of surface area. These methods only enumerate a fraction of heterotrophic bacteria on an agar-based medium under defined incubation temperature and time. To quantify the HPC, it is necessary to scrape the biofilm from the reactor/coupon surface and dilute it to an adequate concentration, before plating. This is a method often used to evaluate biofilm cell numbers in several DWDS models, as the annular reactor (Batté et al., 2003a; Gagnon et al., 2005; Zhou et al., 2009), CDC reactor (Park et al., 2012), flow cell, Propella ${ }^{\circledR}$ reactor (Manuel et al., 2007) and the MRD (Silvestry-Rodriguez et al., 2008).

The microbial metabolic active and total cell numbers are usually assessed through microscopic analysis after a staining process and the results are usually represented in terms of numbers of cells per unit of surface area. 4',6-diamidino-2phenylindole (DAPI) or acridine orange are common dyes used for total cell counts (Percival et al., 1998, 1999; Boe-Hasen et al., 2002; Batté et al., 2003a; Gagnon et al., 2005; Juhna et al., 2007; Manuel et al., 2007; Park et al., 2012). DAPI is a fluorescent stain that binds to A-T rich regions in DNA fluorescing blue, and since it is able to pass through the cell membrane it stains both live and dead cells. Acridine orange is a cell-permeable fluorescent stain that interacts with RNA and DNA fluorescing green to red, providing information on the numbers of total and viable cells (Yu et al., 1995). The BacLight Live/Dead (L/D) stains provide a bacterial viability kit that allows the assessment of both viable and total bacterial cell counts. This kit is composed of two nucleic acid binding stains: SYTO 9 and propidium iodide (PI). SYTO 9 penetrates all bacterial membranes and stains the cells green, while PI only penetrates cells with damaged membranes, and the combination of the two stains produces red fluorescing cells (Simões and Simões, 2013). These stains interact with all the existing biofilm bacteria and their quantification is processed by epiflourescence microscopy. Metabolic active bacteria are usually assessed after being stained by the redox dye 5-cyano-2, 3-ditolyl tetrazolium chloride (CTC) which produces a fluorescent precipitate when it is intracellularly reduced by respiring bacteria (Jungfer et al., 2013; Sierack et al., 1999). This method was used by Gagnon et al. (2005) in an annular reactor, by Manuel et al. (2007) in the Propella ${ }^{\circledR}$ reactor and in the flow cell system, and by Boe-Hasen et al. (2002) in its loop with biofilm test-plug module.

FISH is a procedure used to identify and quantify certain bacteria species within the biofilm community. It consists in the use of fluorescent probes that bind specifically to a nucleic acid sequence. It was used by Park et al. (2012) to investigate the presence of a bacterial species within a biofilm formed in a CDC reactor.

\subsection{EPS quantification}

EPS have a determinant role in biofilm formation and physical stability. They are composed of a variety of organic substances and carbohydrates are its predominant constituents, whereas proteins also exist in substantial quantities. Therefore, the EPS quantification methods are usually based on the analysis of carbohydrates and proteins. However, the reliability of the analysis is strongly dependent on the extraction methods used to separate the EPS from the biofilm cells (Wingender et al., 1999). To quantify the carbohydrates it is often used the modified phenol-sulfuric acid method (Chandy and Angles, 2001; Fang et al., 2010; Percival et al., 1998, 1999). The carbohydrates are broken down by the concentrated sulfuric acid to monosaccharides. Pentoses are then hydrated to furfural and hexoses to hydroxymethyl furfural. These compounds react with phenol and produce a yellow-gold color with a maximum absorption at $490 \mathrm{~nm}$ (DuBois et al., 1956).

For proteins quantification Chandy and Angles (2001) quantified EPS proteins with a protein dye (Coomassie Brilliant Blue). This dye is able to combine with proteins and their amount can be determined spectrophotometrically at $595 \mathrm{~nm}$.

\subsection{Microscopic analysis}

Some microscopic analyses are non-destructive, which means that it allows the direct observation of biofilms without a scraping step. These methods can be advantageous since the possibility of biofilm loss in the scraping process does not 
exist, but also it allows the study of the entire biofilm structure.

AFM is one of these methods and it provides topographic images from the micro- to the nano-scale, providing qualitative and quantitative information on the physico-chemical properties of biofilm-substratum interactions (Beech et al., 2002). Abe et al. (2012) and Mathieu et al. (2014) used this method to study the biofilm behavior in an RDR. Abe et al. (2012) applied AFM techniques, as nano-indentation and chemical force spectrometry, in order to investigate the physico-chemical properties at different formation steps and ages of DW biofilms. The nano-indentation experiments were used in order to investigate the possible presence of macromolecules within a conditioning layer and its contour lengths (maximal extension length of a polymer chain). Chemical force spectrometry was used to assess the substratum and biofilm hydrophobicity. Mathieu et al. (2014) also used AFM to study biofilm cohesiveness through the evaluation of the volume of clusters. To achieve this goal, the surface area of each biofilm aggregate found on the scanned region was analyzed through the corresponding AFM height image. These images were adjusted and treated with a procedure scripted in MATLAB. The program returns the number of biofilm aggregates present in the scanned region, and the surface area and volume of each aggregate.

Another non-destructive microscopic technique is the CSLM. This is a high-technology epifluorescence microscope that creates a thin plane-of-focus, in which out-of-focus light is eliminated (Palmer and Sterneberg, 1999). It was used in several works to study DWDS biofilm formation (Fang et al., 2009) and its behavior to disinfectant action (Fang et al., 2010; Ling and Liu, 2013), where annular reactors and CDC reactors were used as DWDS models. The CSLM allows analyzing the biovolume (spatial size) and the average thickness of biofilms. These both parameters indicate the biofilm amount (Fang et al., 2010; Ling and Liu, 2013). However, to assess these values, the use of fluorescence dyes is essential as the combination of SYTO 9 and propidium iodine to stain cells (The BacLight viability kit) and lectin probes to visualize the biofilm EPS (Fang et al., 2009, 2010; Ling and Liu, 2013).

\subsection{Other quantification methods}

The adenosine triphosphate (ATP) assay is a rapid approach with low detection limits (as low as $0.0001 \mathrm{nM},<5 \%$ deviation) for the indirect assessment of the number of viable cells (Liu et al., 2013). ATP is converted to a luminescent signal (light) in the presence of a combination of a substrate and an enzyme, luciferin and luciferase, respectively. This reaction is called the luciferase reaction in which the mono-oxygenation of luciferin is catalyzed by luciferase in the presence of $\mathrm{Mg}^{2+}$, ATP, and molecular oxygen. The amount of luminescent signal produced is proportional to the amount of ATP present which corresponds to the number of viable cells (Wadhawan et al., 2010). Boe-Hasen et al. (2002) used this technique in the developed loop with biofilm test-plug. This technique was used in DW biofilms to estimate the size and activity of the microbial community. These authors used another method to assess the biofilm formation. It consists in the incorporation of leucine to estimate the protein synthesis rate as a measure of the bacterial growth, after a biofilm dispersion step. Leucine was radioactively labeled and its incorporation was measured by scintillation.

Batté et al. (2003a) used an annular reactor to formed DWDS biofilms and estimated the impact of phosphate-based corrosion inhibitors and the age of biofilm on bacterial cell density using a potential exoproteolytic activity (PEPA) method. This method is used to assess the potential of bacterial cells to hydrolyze proteinic organic matter. It consists in the addition of L-Leucine- $\beta$-Naphthylamide (LL $\beta N)$ to the biofilm suspension. LL $\beta N$ is then hydrolyzed by bacteria and produces $\beta$-Naphthylamide $(\beta \mathrm{N})$ whose fluorescence is measured at $410 \mathrm{~nm}$ excitation and $340 \mathrm{~nm}$ emission wavelengths. The production rate of $\beta \mathrm{N}$ allows the estimation of bacterial biomass, since there is a linear relationship between both aspects (Batté et al., 2003a).

\section{Conclusions}

The development of devices to study DW biofilms aims to mimic real DWDS in order to gather results that can be transposed to reality. The use of an appropriate device is an important factor to obtain reproducible and reliable results and should be selected taking into account the goals of the study. While some of the reactors described in this study are mostly used for lab-scale experiments, other reactors are used in real DWDS or under process conditions similar to those found in DWDS. The application of these devices is diverse, going from studies on biofilm formation, monitoring and behavior to studies on biofilm population dynamics and their control from the DWDS. Even if the amount of information on DW biofilms is significant, the dispersal on the experimental process (hydrodynamics, presence/absence of nutrients, presence/absence of disinfectants, type of disinfectants; type of surface material), environmental (temperature, water characteristics) and biological (type of microorganism, single species or mixed species) conditions used do not allow the selection of a best reactor to study DW biofilms. The advantages and limitations should be evaluated a priori in order to choose an adequate device to obtain reproducible results that can be transposed to the reality of the DWDS.

\section{Acknowledgments}

This work was supported by the Operational Programme for Competitiveness Factors - COMPETE and by Portuguese Foundation for Science and Technology through Project Phytodisinfectants - PTDC/DTPSAP/1078/2012 (COMPETE: FCOMP-01-0124-FEDER-028765), the Post-Doc grant awarded to Lúcia Simões (SFRH/BPD/81982/2011). Also, this work was undertaken as part of the European Research Project SUSCLEAN (Contract n_FP7-KBBE-2011-5, project number: 287514) and the COST Action FA1202. The authors are solely responsible for this work. It does not represent the opinion of the Community, and the Community is not responsible for any use that might be made of data appearing herein. 


\section{R E F E R E N C E S}

Abe, Y., Polyakov, P., Skali-Lami, S., Francius, G., 2011. Elasticity and physico-chemical properties during drinking water biofilm formation. Biofouling 27 (7), 739-750.

Abe, Y., Skali-Lami, S., Block, J.C., Francius, G., 2012. Cohesiveness and hydrodynamic properties of young drinking water biofilms. Water Res. 46 (4), 1155-1166.

Altman, S.J., McGrath, L.K., Souza, C.A., Murton, J.K., Camper, A.K., 2009. Integration and decontamination of Bacillus cereus in Pseudomonas fluorescens biofilms. J. Appl. Microbiol. 107 (1), 287-299.

Armbruster, C.R., Forster, T.S., Donlan, R.M., O'Connell, H.A., Shams, A.M., Williams, M.M., 2012. A biofilm model developed to investigate survival and disinfection of Mycobacterium mucogenicum in potable water. Biofouling 28 (10), 1129-1139.

Bachmann, R.T., Edyvean, R.G.J., 2006. AFM study of the colonisation of stainless steel by Aquabacterium commune. Int. Biodeter. Biodegr. 58 (3-4), 112-118.

Batté, M., Koudjonou, B., Laurent, P., Mathieu, L., Coallier, J., Prevost, M., 2003a. Biofilm responses to ageing and to a high phosphate load in a bench-scale drinking water system. Water Res. 37 (6), 1351-1361.

Batté, M., Mathieu, L., Laurent, P., Prévost, M., 2003b. Influence of phosphate and disinfection on the composition of biofilms produced from drinking water, as measured by fluorescence in situ hybridization. Can. J. Microbiol. 49 (12), 741-753.

Bauman, W.J., Nocker, A., Jones, W.L., Camper, A.K., 2009. Retention of a model pathogen in a porous media biofilm. Biofouling 25 (3), 229-240.

Beech, I.B., Smith, J.R., Steele, A.A., Penegar, I., Campbell, S., 2002. The use of atomic force microscopy for studying interactions of bacterial biofilms with surfaces. Colloids Surf. B 23 (2-3), 231-247.

Beech, I.B., Sunner, J., 2004. Biocorrosion: towards understanding interactions between biofilms and metals. Curr. Opin. Biotechnol. 15 (3), 181-186.

Berry, D., Xi, C., Raskin, L., 2006. Microbial ecology of drinking water distribution systems. Curr. Opin. Biotechnol. 17 (3), 297-302.

Boe-Hasen, R., Albrechtsen, H.J., Arvin, E., Jørgensen, C., 2002. Bulk water phase and biofilm growth in drinking water at low nutrient conditions. Water Res. 36 (18), 4477-4486.

Boe-Hansen, R., Martiny, A.C., Arvin, E., Albrechtsen, H.J., 2003. Monitoring biofilm formation and activity in drinking water distribution networks under oligotrophic conditions. Water Sci. Technol. 47 (5), 91-97.

Bott, T.R., 1993. Aspects of biofilm formation and destruction. Corros. Rev. 11 (1-2), 1-24.

Bragança, S.M., Azevedo, N.F., Simões, L.C., Keevil, C.W., Vieira, M.J., 2007. Use of fluorescent in situ hybridisation for the visualisation of Helicobacter pylori in real drinking water biofilms. Water Sci. Technol. 55 (8-9), 387-393.

Bridier, A., Meylheuc, T., Briandet, R., 2013. Realistic representation of Bacillus subtilis biofilms architecture using combined microscopy (CLSM, ESEM and FESEM). Micron 48, 65-69.

Butterfield, P.W., Camper, A.K., Ellis, B.D., Jones, W.L., 2002. Chlorination of model drinking water biofilm: implications for growth and organic carbon removal. Water Res. 36 (17), 4391-4405.

Camper, A.K., Brastrup, K., Sandvig, A., Clement, J., Spencer, C., Capuzzi, A.J., 2003. Effects of distribution system materials on bacterial regrowth. J. Am. Water Works Assoc. 95 (7), 107-121.

Camper, A.K., 2004. Involvement of humic substances in regrowth. Int. J. Food Microbiol. 92 (3), 355-364.
Carter, J.T., Rice, E.W., Buchberger, S.G., Lee, Y., 2000. Relationships between levels of heterotrophic bacteria and water quality parameters in a drinking water distribution system. Water Res. 34 (5), 1495-1502.

Chandy, J.P., Angles, M.L., 2001. Determination of nutrients limiting biofilm formation and the subsequent impact on disinfectant decay. Water Res. 35 (11), 2677-2682.

Chang, L., Craik, S., 2012. Laboratory simulation of the effect of ozone and monochloramine on biofilms in drinking water mains. Ozone: Sci. Eng. 34 (4), 243-251.

Chang, Y.C., Le Puil, M., Biggerstaff, J., Randall, A.A., Schulte, A., Taylor, J.S., 2003. Direct estimation of biofilm density on different pipe material coupons using a specific DNA-probe. Mol. Cell. Probes 17 (5), 237-243.

Characklis, W.G., Marshall, K.C., 1990. Biofilms. In: Wiley Series in Ecological andApplied Microbiology. John Wiley \& Sons, USA, $288 \mathrm{pp}$.

Childs, P.R.N., 2011. Rotating flow. Elsevier, ButterworthHeinemann, UK, p. 177, pp. 193-203 (Chapter 6).

Codony, F., Morató, J., Mas, J., 2005. Role of discontinuous chlorination on microbial production by drinking water biofilms. Water Res. 39 (9), 1896-1906.

Dailloux, M., Albert, M., Laurain, C., Andolfatto, S., Lozniewski, A., Hartemann, P., Mathieu, L., 2003. Mycobacterium xenopi and drinking water biofilms. Appl. Environ. Microbiol. 69 (11), 6946-6948.

Deines, P., Sekar, R., Husband, P.S., Boxall, J.B., Osborn, A.M., Biggs, C.A., 2010. A new coupon design for simultaneous analysis of in situ microbial biofilm formation and community structure in drinking water distribution systems. Appl. Microbiol. Biotechnol. 87 (2), 749-756.

Delahaye, E., Levi, Y., Leblon, G., Montiel, A., 2006. A simple system for biofilm potential monitoring in drinking water. J. Basic Microbiol. 46 (1), 22-27.

Douterelo, I., Sharpe, R.L., Boxall, J.B., 2013. Influence of hydraulic regimes on bacterial community structure and composition in an experimental drinking water distribution system. Water Res. 47 (2), 503-516.

DuBois, M., Gilles, K.A., Hamilton, J.K., Rebers, P.A., Smith, F., 1956. Colorimetric method for determination of sugars and related substances. Anal. Chem. 28 (3), 350-356.

Dykstra, T.S., O'Leary, K.C., Chauret, C., Andrews, R.C., Gagnon, G.A., 2007. Impact of UV and secondary disinfection on microbial control in a model distribution system. J. Environ. Eng. Sci. 6 (2), 147-155.

Emtiazi, F., Schwartz, T., Marten, S.M., Krolla-Sidenstein, P., Obst, U., 2004. Investigation of natural biofilms formed during the production of drinking water from surface water embankment filtration. Water Res. 38 (5), 1197-1206.

Fang, W., Hu, J.Y., On, S.L., 2009. Influence of phosphorus on biofilm formation in model drinking water distribution systems. J. Appl. Microbiol. 106 (4), 1328-1335.

Fang, W., Hu, J., Ong, S.L., 2010. Effects of phosphorus on biofilm disinfections in model drinking water distribution systems. J. Water Health 8 (3), 446-454.

Gagnon, G.A., O'Leary, K.C., Volk, C.J., Chauret, C., Stover, L., Andrews, R.C., 2004. Comparative analysis of chlorine dioxide, free chlorine and chloramines on bacterial water quality in model distribution systems. J. Environ. Eng. 130 (11), 1269-1279.

Gagnon, G.A., Rand, J.L., O'Leary, K.C., Rygel, A.C., Chauret, C., Andrews, R.C., 2005. Disinfectant efficacy of chlorite and chlorine dioxide in drinking water biofilms. Water Res. 39 (9), 1809-1817.

Gião, M.S., Azevedo, N.F., Wilks, S.A., Vieira, M.J., Keevil, C.W., 2008. Persistence of Helicobacter pylori in heterotrophic drinking-water biofilms. Appl. Environ. Microbiol. 74 (19), 5898-5904. 
Gião, M.S., Azevedo, N.F., Wilks, S.A., Vieira, M.J., Keevil, C.W., 2011. Interaction of Legionella pneumophila and Helicobacter pylori with bacterial species isolated from drinking water biofilms. BMC Microbiol. 11 (57).

Ginige, M.P., Wylie, J., Plumb, J., 2011. Influence of biofilms on iron and manganese deposition in drinking water distribution systems. Biofouling 27 (2), 151-163.

Goeres, D.M., Loetterle, L.R., Hamilton, M.A., Murga, R., Kirby, D.W., Donlan, R.M., 2005. Statistical assessment of a laboratory method for growing biofilms. Microbiology 151 (3), 757-762.

Goeres, D.M., 2006. Design of Model Reactor System for Evaluating Disinfectants against Biofilm Bacteria (PhD dissertation). Montana State University.

Gosselin, F., Madeira, L.M., Juhna, T., Block, J.C., 2013. Drinking water and biofilm disinfection by Fenton-like reaction. Water Res. 47 (15), 5631-5638.

Hallam, N.B., West, J.R., Forster, C.F., Simms, J., 2001. The potential for biofilm growth in water distribution systems. Water Res. 35 (17), 4063-4071.

Helmi, K., Menard-Szczebara, F., Lénès, D., Jacob, P., Jossent, J., Barbot, C., Delabre, K., Arnal, C., 2010. Adenovirus, MS2 and PhiX174 interactions with drinking water biofilms developed on PVC, cement and cast iron. Water Sci. Technol. 61 (12), 3198-3207.

Henne, K., Kahlisch, L., Brettar, I., Höfle, M.G., 2012. Analysis of structure and composition of bacterial core communities in mature drinking water biofilms and bulk water of a citywide network in Germany. Appl. Environ. Microbiol. 78 (10), 3530-3538.

Hosni, A.A., Szabo, J.G., Bishop, P.L., 2011. Efficacy of chlorine dioxide as a disinfectant for Bacillus spores in drinking-water biofilms. J. Environ. Eng. 137 (7), 569-574.

Huang, C.-T., Peretti, S.W., Bryers, J.D., 1992. Use of flow cell reactors to quantify biofilm formation kinetics. Biotechnol. Tech. 6 (3), 193-198.

Jang, H.J., Choi, Y.J., Ka, J.O., 2011. Effects of diverse water pipe materials on bacterial communities and water quality in the annular reactor. J. Microbiol. Biotechnol. 21 (2), 115-123.

Jang, H.J., Choi, Y.J., Ro, H.M., Ka, J.O., 2012. Effects of phosphate addition on biofilm bacterial communities and water quality in annular reactors equipped with stainless steel and ductile cast iron pipes. J. Microbiol. 50 (1), 17-28.

Jass, J., Costerton, J.W., Lappin-Scott, H.M., 1995. Assessment of a chemostat-coupled modified Robbins device to study biofilms. J. Ind. Microbiol. 15 (4), 283-289.

Juhna, T., Birzniece, D., Larsson, S., Zulenkovs, D., Sharipo, A., Azevedo, N.F., Ménard-Szczebara, F., Castagnet, S., Féliers, C., Keevil, C.W., 2007. Detection of Escherichia coli in biofilms from pipe samples and coupons in drinking water distribution networks. Appl. Environ. Microbiol. 73 (22), 7456-7464.

Jungfer, C., Friedrich, F., Varela, J.V., Brandle, K., Gross, H.J., Obst, U., Schwartz, T., 2013. Drinking water biofilms on cooper and stainless steel exhibit specific molecular responses towards different disinfection regimes at water works. Biofouling 29 (8), 891-907.

Kalmbach, S., Manz, W., Szewyk, U., 1997. Dynamics of biofilm formation in drinking water: phylogenetic affiliation and metabolic potential of single cells assessed by formazan reduction and in situ hybridization. FEMS Microbiol. Ecol. 22 (4), 265-279.

Keinänen-Toivola, M.M., Revetta, R.P., Santo Domingo, J.W., 2006. Identification of active bacterial communities in a model drinking water biofilm system using $16 \mathrm{~S}$ rRNA-based clone libraries. FEMS Microbiol. Lett. 257 (2), 182-188.

Kerr, C.J., Jones, C.R., Hillier, V.F., Robson, G.D., Osborn, K.S., Handley, P.S., 2000. Statistical evaluation of a newly modified Robbins device using a bioluminescent pseudomonad to quantify adhesion to plastic. Biofouling 14 (4), 267-277.
Långmark, J., Storey, M.V., Ashbolt, N.J., Stenström, T.A., 2005. Accumulation and fate of microorganisms and microspheres in biofilms formed in a pilot-scale water distribution system. Appl. Environ. Microbiol. 71 (2), 706-712.

LeChevallier, M., Norton, C., Camper, A., Morin, P., Ellis, B., Jones, W., Rompré, A., Prevost, M., Coallier, J., Servais, P., Holt, D., Delanowe, A., Colbourn, J., 1998. Microbial Impact of Biological Filtration. AWWA Research Foundation, USA, pp. 140-154.

Lehtola, M.J., Miettinen, I.T., Martikainen, P.J., 2002. Biofilm formation in drinking water affected by low concentrations of phosphorus. Can. J. Microbiol. 48 (6), 494-499.

Lehtola, M.J., Torvinen, E., Miettinen, I.T., Keevil, C.W., 2006. Fluorescence in situ hybridization using peptide nucleic acid probes for rapid detection of Mycobacterium avium subsp. avium and Mycobacterium avium subsp. paratuberculosis in potable-water biofilms. Appl. Environ. Microbiol. 72 (1), 848-853.

Lehtola, M.J., Torvinen, E., Kusnetsov, J., Pitkänen, T., Maunula, L., Von Bonsdorff, C.H., Martikainen, P.J., Wilks, S.A., Keevil, C.W., Miettinen, I.T., 2007. Survival of Mycobacterium avium, Legionella pneumophila, Escherichia coli, and Calicivirases in drinking water-associated biofilms grown under high-shear turbulent flow. Appl. Environ. Microbiol. 73 (9), 2854-2859.

Lin, W., Yu, Z., Chen, X., Lui, R., Zhang, H., 2013. Molecular characterization of natural biofilms from household taps with different materials: PVC, stainless steel, and cast iron in drinking water distribution system. Appl. Microbiol. Biotechnol. 97 (18), 8393-8401.

Lin, W., Yu, Z., Zhang, H., Thompson, I.P., 2014. Diversity and dynamics of microbial communities at each step of treatment plant for potable water generation. Water Res. 52, 218-230.

Ling, F., Liu, W.T., 2013. Impact of chloramination on the development of laboratory grown biofilms fed with filterpretreated groundwater. Microb. Environ. 28 (1), 50-57.

Liu, G., Verberk, J.Q., Van Dijk, J.C., 2013. Bacteriology of drinking water distribution systems: an integral and multidimensional review. Appl. Microbiol. Biotechnol. 97 (21), 9256-9276.

Lu, P., Chen, C., Wang, Q., Wang, Z., Zhang, X., Xie, S., 2013. Phylogenetic diversity of microbial communities in real drinking water distribution systems. Biotechnol. Bioproc. Eng. 18, 119-124.

Manuel, C.M., Nunes, O.C., Melo, L.F., 2007. Dynamics of drinking water biofilm in flow/non-flow conditions. Water Res. 41 (3), 551-562.

Manuel, C.M., Nunes, O.C., Melo, L.F., 2010. Unsteady state flow and stagnation in distribution systems affect the biological stability of drinking water. Biofouling 26 (2), 129-139.

Manz, W., Szewzyk, U., Ericsson, P., Amann, R., Schleifer, K.H., Stenstrom, T.A., 1993. In situ identification of bacteria in drinking water and adjoining biofilms by hybridization with 16S and 23S rRNA-directed fluorescent oligonucleotide probes. Appl. Environ. Microbiol. 59 (7), 2293-2298.

Mathieu, L., Bertrand, I., Abe, Y., Angle, E., Block, J.C., SkaliLami, S., Francius, G., 2014. Drinking water biofilm cohesiveness changes under chlorination or hydrodynamic stress. Water Res. 55, 175-184.

Melo, L.F., Bott, T.R., 1997. Biofouling in water systems. Exp. Therm. Fluid Sci. 14 (4), 375-381.

Morato, J., Codony, F., Mas, J., 2005. Utilisation of a packed-bed biofilm reactor for the determination of the potential of biofilm accumulation in water systems. Biofouling 21 (3-4), 151-160.

Morin, P., Camper, A.K., 1997. Attachment and fate of carbon fines in simulated drinking water distribution system biofilms. Water Res. 31 (3), 399-410.

Morrow, J.B., Almeida, J.L., Fitzgerald, L.A., Cole, K.D., 2008. Association and decontamination of Bacillus spores in a 
simulated drinking water system. Water Res. 42 (20), 5011-5021.

Murga, R., Forster, T.S., Brown, E., Pruckler, J.M., Fields, B.S., Donlan, R.M., 2001. Role of biofilms in the survival of Legionella pneumophila in a model potable-water system. Microbiology 147 (11), 3121-3126.

Murphy, H.M., Payne, S.J., Gagnon, G.A., 2008. Sequential UV- and chlorine-based disinfection to mitigate Escherichia coli in drinking water biofilms. Water Res. 42 (8-9), 2083-2092.

Ndiongue, S., Huck, P.M., Slawson, R.M., 2005. Effects of temperature and biodegradable organic matter on control of biofilms by free chlorine in a model drinking water distribution system. Water Res. 39 (6), 953-964.

Nesic, S., Solvi, G.T., Skjerves, S., 1997. Comparison of rotating cylinder and loop methods for testing $\mathrm{CO}_{2}$ corrosion inhibitors. Corr. Eng. Sci. Technol. 32 (4), 269-276.

Nickel, J.C., Ruseska, I., Wright, J.B., Costerton, J.W., 1985. Tobramycin resistance of Pseudomonas aeruginosa cells growing as a biofilm on urinary catheter material. Antimicrob. Agents Chemother. 27 (4), 619-624.

O'Toole, G., Kaplan, H.B., Kolter, R., 2000. Biofilm formation as microbial development. Annu. Rev. Microbiol. 54 (1), 49-79.

Okabe, S., Hirata, K., Watanabe, Y., 1995. Dynamic changes in spatial microbial distribution in mixed-population biofilms: experimental results and model simulation. Water Sci. Technol. 32 (8), 67-74.

Ollos, P.J., Huck, P.M., Slawson, R.M., 2003. Factors affecting biofilm accumulation in model distribution systems. J. Am. Water Works Assoc. 95 (1), 87-97.

Palmer, R.J., Sterneberg, C., 1999. Modern microscopy in biofilm research: confocal microscopy and other approaches. Curr. Opin. Biotechnol. 10 (3), 263-268.

Paris, T., Skali-Lami, S., Block, J.C., 2007. Effect of wall shear rate on biofilm deposition and grazing in drinking water flow chambers. Biotechnol. Bioeng. 97 (6), 1550-1561.

Paris, T., Skali-Lami, S., Block, J.C., 2009. Probing young drinking water biofilms with hard and soft particles. Water Res. 43 (1), 117-126.

Park, S.K., Hu, J.Y., 2010. Assessment of the extent of bacterial growth in reverse osmosis system for improving drinking water quality. J. Environ. Sci. Health 45 (8), 968-977.

Park, S.-K., Choi, J.-H., Hu, J.Y., 2012. Assessing bacterial growth potential in a model distribution system receiving nanofiltration membrane treated water. Desalination 296, $7-15$.

Pedersen, K., 1982. Method for studying microbial biofilms in flowing-water systems. Appl. Environ. Microbiol. 43 (1), 6-13.

Pelleïeux, S., Bertrand, I., Skali-Lami, S., Mathieu, L., Francius, G., Gantzer, C., 2012. Accumulation of MS2, GA, and Q $\beta$ phages on high density polyethylene (HDPE) and drinking water biofilms under flow/non-flow conditions. Water Res. 46 (19), 6574-6584.

Percival, S.L., Knapp, J.S., Edyvean, R.G.J., Wales, D.S., 1998. Biofilms, mains water and stainless steel. Water Res. 32 (7), 2187-2220.

Percival, S.L., Knapp, J.S., Wales, D.S., Edyvean, R.G.J., 1999. The effect of turbulent flow and surface roughness on biofilm formation in drinking water. J. Ind. Microbiol. Biotechnol 22 (3), 152-159.

Pérez, J.A.S., Porcel, E.M.R., López, J.L.C., Sevilla, J.M.F., Chisti, Y., 2006. Shear rate in stirred tank and bubble column bioreactors. Chem. Eng. J. 124 (1-3), 1-5.

Pintar, K.D.M., Slawson, R.M., 2003. Effect of temperature and disinfection strategies on ammonia-oxidizing bacteria in a bench-scale drinking water distribution system. Water Res. 37 (8), 1805-1817.

Prévost, M., Rompré, A., Coallier, J., Servais, P., Laurent, P., Clément, B., Lafrance, P., 1998. Suspended bacteria biomass and activity in full-scale drinking water distribution system: impact of water treatment. Water Res. 32 (5), 1393-1406.

Rand, J.L., Hofmann, R., Alam, M.Z.B., Chauret, C., Cantwell, R., Andrews, R.C., Gagnon, G.A., 2007. A field study evaluation for mitigating biofouling with chlorine dioxide or chlorine integrated with UV disinfection. Water Res. 41 (9), 1939-1948.

Rickard, A.H., McBain, A.J., Stead, A.T., Gilbert, P., 2004. Shear rate moderates community diversity in freshwater biofilms. Appl. Environ. Microbiol. 70 (12), 7426-7435.

Rochex, A., Godon, J.J., Bernet, N., Escudie, R., 2008. Role of shear stress on composition, diversity and dynamics of biofilm bacterial communities. Water Res. 42 (20), 4915-4922.

Rubulis, J., Juhna, T., 2007. Evaluating the potential of biofilm control in water supply systems by removal of phosphorus from drinking water. Water Sci. Technol. 55 (8-9), 211-217.

Sammon, N.B., Harrower, K.M., Fabbro, L.D., Reed, R.H., 2011. Three potential sources of microfungi in a treated municipal water supply system in sub-tropical Australia. Int. J. Environ. Res. Public Health 8 (3), 713-732.

Schaule, G., Moschnitschka, D., Schulte, S., Tamachkiarow, A., Flemming, H.C., 2007. Biofilm growth in response to various concentrations of biodegradable material in drinking water. Water Sci. Technol. 55 (8-9), 191-195.

Schlichting, H., 1955. Boundary-Layer Theory. Mc Graw-Hill, New York, $535 \mathrm{pp}$.

Sharp, R.R., Camper, A.K., Crippen, J.J., Schneider, O.D., Leggiero, S., 2001. Evaluation of drinking water biostability using biofilm methods. J. Environ. Eng. 127 (5), 403-410.

Sierack, M.E., Cucci, T.L., Nicinski, J., 1999. Flow cytometric analysis of 5-cyano-2,3-ditolyl tetrazolium chloride activity of marine bacterioplankton in dilution cultures. Appl. Environ. Microbiol. 65 (6), 2409-2417.

Silvestry-Rodriguez, N., Bright, K.R., Slack, D.C., Uhlmann, D.R., Gerba, C.P., 2008. Silver as a residual disinfectant to prevent biofilm formation in water distribution systems. Appl. Environ. Microbiol. 74 (5), 1639-1641.

Simões, L.C., Azevedo, N., Pacheco, A., Keevil, C.W., Vieira, M.J., 2006. Drinking water biofilm assessment of total and culturable bacteria under different operating conditions. Biofouling 22 (2), 91-99.

Simões, L.C., Simões, M., Vieira, M.J., 2007. Biofilm interactions between distinct bacterial genera isolated from drinking water. Appl. Environ. Microbiol. 73 (19), 6192-6200.

Simões, L.C., Simões, M., Vieira, M.J., 2008. Intergeneric coaggregation among drinking water bacteria: evidence of a role for Acinetobacter calcoaceticus as a bridging bacterium. Appl. Environ. Microbiol. 74 (4), 1259-1263.

Simões, L.C., Simões, M., Vieira, M.J., 2010a. Adhesion and biofilm formation on polystyrene by drinking water-isolated bacteria. Antonie van Leeuwenhoek, Int. J. Gen. Mol. Microbiol. 98 (3), 317-329.

Simões, L.C., Simões, M., Vieira, M.J., 2010b. Influence of the diversity of bacterial isolates from drinking water on resistance of biofilms to disinfection. Appl. Environ. Microbiol. 76 (19), 6673-6679.

Simões, L.C., Simões, M., Vieira, M.J., 2011. The effects of metabolite molecules produced by drinking water-isolated bacteria on their single and multispecies biofilms. Biofouling 27 (7), 685-699.

Simões, L.C., Simões, M., Vieira, M.J., 2012. A comparative study of drinking water biofilm monitoring with flow cell and Propella ${ }^{\mathrm{TM}}$ bioreactors. Water Sci. Technol. 12 (3), 334-342.

Simões, L.C., Simões, M., 2013. Biofilms in drinking water: problems and solutions. RSC Adv. 3 (8), 2520-2533.

Siqueira, V.M., Oliveira, H.M.B., Santos, C., Paterson, R.R.M., Gusmão, N.B., Lima, N., 2011. Filamentous fungi in drinking water, particularly in relation to biofilm formation. Int. J. Environ. Res. Public Health 8 (2), 456-469. 
Siqueira, V.M., Oliveira, H.M.B., Santos, C., Paterson, R.R.M., Gusmão, N.B., Lima, N., 2013. Biofilms from a Brazilian water distribution system include filamentous fungi. Can. J. Microbiol. 59 (3), 183-188.

Sly, L.I., Hodgkinson, M.C., Arunpairojana, V., 1990. Deposition of manganese in a drinking water distribution system. Appl. Environ. Microbiol. 56 (3), 628-639.

Stoodley, P., Dodds, I., Boyle, J.D., Lappin-Scott, H.M., 1999. Influence of hydrodynamics and nutrients on biofilm structure. J. Appl. Microbiol. Symp. Suppl. 85 (28), 19S-28S.

Szabo, J.G., Rice, E.W., Bishop, P.L., 2006. Persistence of Klebsiella pneumoniae on simulated biofilm in a model drinking water system. Environ. Sci. Technol. 40 (16), 4996-5002.

Teng, F., Guan, Y.T., Zhu, W.P., 2008. Effect of biofilm on cast iron pipe corrosion in drinking water distribution system: corrosion scales characterization and microbial community structure investigation. Corros. Sci. 50 (10), 2816-2823.

Teodósio, J.S., Simões, M., Alves, M.A., Melo, L.F., Mergulhão, F.J., 2012. Setup and validation of flow cell systems for biofouling simulation in industrial settings. Sci. World J. 2012, 180-187.

Torvinen, E., Lehtola, M.J., Martikainen, P.J., Miettinen, I.T., 2007. Survival of Mycobacterium avium in drinking water biofilms as affected by water flow velocity, availability of phosphorus, and temperature. Appl. Environ. Microbiol. 73 (19), 6201-6207.

van der Kooij, D., Veenendaal, H.R., Baars-Lorist, C., van der Klift, D.W., Drost, Y.C., 1995. Biofilm formation on surfaces of glass and Teflon exposed to treated water. Water Res. 29 (7), 1655-1662.

van der Kooij, D., 1999. Potential for biofilm development in drinking water distribution systems. J. Appl. Microbiol. Symp. Suppl. 85 (28), 39S-44S.

Volk, C.J., LeChevallier, M.W., 1999. Impacts of the reduction of nutrient levels on bacterial water quality in distribution systems. Appl. Environ. Microbiol. 65 (11), 4957-4966.

Wadhawan, T., McEvoy, J., Prüß, B.M., Khan, E., 2010. Assessing tetrazolium and ATP assays for rapid in situ viability quantification of bacterial cells entrapped in hydrogel beads. Enzyme Microb. Technol. 47 (4), 166-173.

WHO, 2011. Guidelines for Drinking Water Quality, fourth ed. World Health Organization.

Wilks, S.A., Keevil, C.W., 2003. Structure of diverse species potable water biofilms under defined shear flow regimes in the Propella ${ }^{\circledR}$ reactor. In: McBain, A., Allison, D., Branding, M., Rickard, A., Verran, J., Walker, J. (Eds.), Biofilm Communities: Order from Chaos? Bioline, Cardiff, UK.

Willcock, L., Gilbert, P., Holah, J., Wirtanen, G., Allison, D.G., 2000. A new technique for the performance evaluation of clean-inplace disinfection of biofilms. J. Ind. Microbiol. Biotechnol. 25 (5), 235-241.

Wingender, J., Neu, T.R., Flemming, H.C., 1999. Microbial Extracellular Polymeric Substances: Characterization, Structures and Function. Springer-Verlag, Berlin, Heidelberg (Chapter 3).

Wingender, J., Flemming, H.C., 2004. Contamination potential of drinking water distribution network biofilms. Water Sci. Technol. 49 (11-12), 277-286.

Yu, W., Doods, W.K., Banks, M.K., Skalsky, J., Strauss, E.A., 1995. Optimal staining and sample storage time for direct microscopic enumeration of total and active bacteria in soil with two fluorescent dyes. Appl. Environ. Microbiol. 6 (9), 3367-3372.

Yu, J., Kim, D., Lee, T., 2010. Microbial diversity in biofilms on water distribution pipes of different materials. Water Sci. Technol. 61 (1), 163-171.

Zhang, Y., Zhou, L., Zeng, G., Deng, H., Li, G., 2010. Impact of total organic carbon and chlorine to ammonia ratio on nitrification in a bench-scale drinking water distribution system. Front. Environ. Sci. Eng. China 4 (4), 430-437.

Zhou, L.L., Zhang, Y.J., Li, G.B., 2009. Effect of pipe material and low level disinfectants on biofilm development in a simulated drinking water distribution system. J. Zhejiang Univ. Sci. A 10 (5), 725-731. 